\title{
Transport of $E$. coli in saturated and unsaturated porous media: effect of physiological state and substrate availability
}

\author{
G MADUMATHI, LIGY PHILIP and S MURTY BHALLAMUDI* \\ Department of Civil Engineering, Indian Institute of Technology Madras, Chennai 600036, India \\ e-mail: bsm@iitm.ac.in
}

MS received 13 June 2016; revised 25 November 2016; accepted 1 January 2017

\begin{abstract}
Saturated and unsaturated sand and soil column experiments were conducted to study the complex interaction between the effects of biological and hydrological factors on the transport of bacteria through a porous medium. These experiments were conducted with continuous input of bacteria and substrate at the inlet to reflect the groundwater contamination caused by leaking septic tanks and leach pits. Experiments were conducted with metabolically active and inactive Escherichia coli. Cell surface characteristics and batch experimental data for bacterial attachment were correlated with the transport behaviour in continuous column studies. Normalized breakthrough concentration for metabolically inactive cells $\left(C / C_{0}=0.74\right.$ in sand) was higher than that for active cells $\left(C / C_{0}=0.68\right.$ in sand) owing to change in cell surface characteristics. A similar trend was observed in the case of transport through soil columns. There was an increase of $29.5 \%$ in the peak $C /$ $C_{0}$ value at the outlet when the flow velocity was increased from $0.0535 \mathrm{~cm} / \mathrm{h}\left(C / C_{0}=0.61\right)$ to $0.214 \mathrm{~cm} / \mathrm{h}(C /$ $\left.C_{0}=0.79\right)$ in case of sand columns. However, this difference was only $20 \%$ in case of soil columns. Peak normalized concentrations at the outlet were less in soil column as compared to those in sand column because of lesser grain size. Unlike the earlier studies with pulse input, present experiments with continuous input of metabolically active bacteria along with substrate indicated that the normalized concentration at the outlet increased with increased concentration at the inlet. It was found that unsaturated conditions led to more retention of bacteria in both sand and soil columns. In case of sand columns, the normalized concentration at the exit reduced to as much as 0.46 . It was also found that the existing mathematical models based on macroscopic advection-dispersion-filtration equations could satisfactorily simulate the bacterial transport except in a case where the substrate was added to the bacteria in the column studies.
\end{abstract}

Keywords. E. coli; transport; column studies; metabolically inactive; substrate availability.

\section{Introduction}

Groundwater is a major source of drinking water in many places. However, its quality has been deteriorating in many developing countries due to microbial contamination resulting from poor sanitation conditions. Stagnant wastewater bodies, livestock operations, land application of sewage, sanitary landfills and leaking on-site wastewater treatment systems such as septic tanks introduce microorganisms into sub-surface water bodies [1]. USAID [2] has reported that the number of households having septic tanks in urban India will increase from 30 million in 2010 to 148 million by 2017. Approximately $40-85 \%$ of sewage treatment in Asian countries such as Thailand, the Philippines and Vietnam is through septic tanks.

Electronic supplementary material The online version of this article (doi:10.1007/s12046-017-0650-8) contains supplementary material, which is available to authorized users.

*For correspondence
Even in Malaysia, where almost $100 \%$ of domestic wastewater is treated, $27 \%$ is treated by septic tanks [2]. Field investigations have indicated that improper siting, faulty design and construction, and poor operation conditions of on-site systems such septic tanks and pit latrines, can contribute significantly to groundwater contamination [3]. Laluraj and Gopinath [4] reported that aquifers along the coastal zone of central Kerala in India have a high incidence of faecal coliform, ranging from 93 to $460 \mathrm{MPN}$ (FC)/100 mL, indicating poor sanitary conditions and improper waste disposal. Therefore, several urban local bodies have brought out policies regarding the safe distance between a septic tank and the nearest drinking water well [5]. However, most of these guidelines are ad hoc in nature. In this context, it is important to understand the factors and processes which affect the attenuation in the bacterial concentration as the bacteria get transported in the saturated and unsaturated porous media.

Significant amount of research has been carried out to understand how physical parameters such as nature of porous media, temperature and fluid velocity; chemical 
parameters such as ionic strength, valency of ions and $\mathrm{pH}$; and biological factors such as cell type, hydrophobicity, surface charge and bacterial concentration affect the bacterial transport through a saturated porous medium [6, 7]. While many earlier bacterial transport studies have been simplified to limit the system to no-growth conditions, Jansen et al [8] found from their experiments on transport of Pseudomonas fluorescens in saturated columns that the substrate addition led to two consecutive breakthrough peaks and more bacteria were retained in the column when substrate was added. Another important factor which affects the bacterial transport in groundwater is the metabolic state of bacteria [9], which in turn may get affected by the processes occurring in a septic tank. Li et al [10] found that longer retention periods in treated wastewater decreased bacterial deposition rates and increased the transport potential in sand columns. Their studies are limited to the transport of different strains of Escherichia coli in the absence of any substrate. Jansen et al [8] conducted studies to understand the role of metabolic state in the transport and deposition behaviour of Pseudomonas fluorescens with and without substrate addition. All the earlier experimental studies were limited to transport through columns containing pure quartz sand. However, natural porous media typically exhibit a wide range in pore sizes due to variations in grain size, orientation, configuration and surface roughness, which affect the straining of nonspherical colloids in the porous media [11]. Based on a recent study on transport of $E$. coli strains harvested from springs in Uganda, Lutterodt et al [12] concluded that identifying causal relationships between $E$. coli surface characteristics and retention of $E$. coli in sediment upon transport in groundwater is still a challenge.

Flow and transport mechanisms become further complicated in the unsaturated zone due to the presence of the gaseous phase, flow discontinuities and wetting history [13]. A number of studies have been carried out since early times to understand the effects of water content [14], ionic strength [15], hydrophilic/hydrophobic nature of bacteria [16], different interfaces [17] and grain size [18] on bacterial transport through unsaturated porous media. Studies carried out by Powelson and Mills [19] showed that unsaturated columns always had delayed cell breakthrough compared with saturated columns. Study by Jiang et al [20] suggested that soils with higher topsoil clay content and soils under flood irrigation are at a high risk of bacteria leaching through preferential flow paths. Experiments conducted by Chen and Walker [21] showed that different surface characteristics of two different bacterial species led to their distinct transport and retention behaviour. A field study conducted by Rao et al [22] indicated that 4-m thick unsaturated zone resulted in removal of $1 \log$ of $E$. coli pathogen. Much of the earlier work on bacterial transport considered only steady-state flow conditions, while transient flows (e.g., infiltration and drainage) are more common in nature. Colloid mobilization is generally considered to be very small in unsaturated systems during steady-state flow [23]. However, based on column experiments with intermittent flow conditions, Auset et al [24] reported that most of the released bacteria came after the second water pulse. Imbibition could cause microbial mobilization due to faster flow, which increases shear forces on the attached microbes [25]. The frequency of pulses can also affect the total re-mobilization rate [20].

Most of the earlier experimental studies have examined transport and survival processes separately because of complexities involved, even though there is a significant interplay between these processes [26]. Also, in many studies, both bacteria and substrate were applied as short pulses at the inlet to the column. This inlet condition does not truly depict the contamination of groundwater from faulty septic tanks and leach pits, as the supply of both substrate and bacteria to the groundwater would be continuous in such a situation. A review of literature indicated that further experimental studies are needed to gain an insight into the complex interplay between the effects of biological factors such as (i) availability of substrate and (ii) metabolic state (live vs. inactive) of the bacteria, and hydrological factors such as groundwater velocity, type of soil, and flow conditions (continuous vs. intermittent; saturated vs. unsaturated) on the transport of pathogenic bacteria through a porous medium. Such studies will aid in policy decisions for protecting drinking groundwater sources from improper sanitation systems. Therefore, in this study, saturated and unsaturated, sand and soil column experiments were conducted with active and inactive $E$. coli bacteria. Saturated column experiments were conducted for continuous input of bacteria at the inlet to reflect the groundwater contaminated by septic systems. Column studies for metabolically active bacteria were also conducted with continuous input of substrate. The role of transient flow in mobilizing colloids through unsaturated porous medium was investigated. Saturated and unsaturated column experiments were conducted using the same bacteria in order to bring out the difference in the transport behaviour due to unsaturated conditions. Batch experiments were conducted to investigate the effect of metabolic state on the attachment process. These results were correlated to the transport behaviour in continuous column studies. Finally, the experimental data obtained in this study are used to evaluate the applicability of presently available mathematical models for simulating the fate and transport of bacteria in saturated and unsaturated porous media.

\section{Materials and methods}

\subsection{Chemicals}

All the chemicals used in this study were of analytical reagent (AR) grade and were supplied by Ranbaxy Chemicals Limited., Chennai, India. All solutions were prepared either in fresh distilled water or in de-ionised water as required. 


\subsection{Sand}

For sand column experiments, river sand was sieved and the fraction of the sand retained between 300 and $500 \mu \mathrm{m}$ in size was collected. The resulting average sand diameter was $400 \mu \mathrm{m}$. The sand was cleaned with $\mathrm{HNO}_{3}, \mathrm{NaOH}$ and deionized water as per the procedure described by Lenhart and Saiers [27] to remove metal oxides and trace organics. Sand was washed thoroughly with distilled water and oven dried at $100^{\circ} \mathrm{C}$ overnight. It was then sterilized by autoclaving prior to the use in column study. Sand was classified through sieve analysis and Atterberg's limit analysis. The organic matter content and specific gravity of the sand were determined by chromic acid method [28] and pyknometer method [29]. The results are presented in table 1.

\subsection{Soil}

For soil column experiments, soil was collected from the nursery of IIT Madras at a depth of $1 \mathrm{~m}$. The median grain size of the soil was found to be $320 \mu \mathrm{m}$. It was washed thoroughly with distilled water and oven dried at $100^{\circ} \mathrm{C}$ overnight. Soil was then sterilized by autoclaving prior to column study. The organic matter content and specific gravity of the soil were determined by chromic acid method [28] and pyknometer method [29]. Soil was classified as silty sand as per ASTM (American Society for Testing and Material) standards. The results are presented in table 1 .

\subsection{Determination of soil water characteristics using pressure plate apparatus}

The soil water characteristic (SWC) curve describes the functional relationship between soil water content and

Table 1. Characteristics of soil and sand used in the present study.

\begin{tabular}{lccc}
\hline $\begin{array}{l}\text { Serial } \\
\text { no }\end{array}$ & Properties & $\begin{array}{c}\text { Values (mass } \\
\% \text { ) sand }\end{array}$ & $\begin{array}{c}\text { Values (mass } \\
\% \text { ) soil }\end{array}$ \\
\hline 1 & Gravel & $0 \%$ & $5.5 \%$ \\
2 & Silt content & $0 \%$ & $16.35 \%$ \\
3 & Sand content & $100 \%$ & $73.52 \%$ \\
4 & Organic content & ND & 0.68 \\
5 & Specific gravity & 2.650 & 2.56 \\
6 & Bulk density (mg/cm $\left.{ }^{3}\right)$ & 1600 & 1560 \\
7 & Porosity & 0.4 & 0.37 \\
8 & pH & 6.7 & 7.48 \\
9 & Van Genuchten & 0.0038 & 0.145 \\
& parameter $(\alpha)\left(\mathrm{cm}{ }^{-1}\right)$ & & \\
10 & Van Genuchten & 2.78 & 2.68 \\
& parameter $(\mathrm{n})$ & & \\
\hline
\end{tabular}

matric potential under equilibrium conditions. To determine the SWC, laboratory measurements were carried out with pressure plate apparatus. It consists of a pressure chamber enclosing a water-saturated porous plate which allows water but prevents air flow through its pores. The porous plate is open to atmospheric pressure at the bottom surface, while the top surface is at the applied pressure of the chamber. Free water was maintained on the plate surface until the soil was thoroughly wetted. After saturation was attained, the porous plate with the saturated soil samples was placed in the chamber and air pressure was applied to force water out of the soil and through the plate. Flow continued until equilibrium was attained between the force exerted by the air pressure and the force by which soil water was being held by the soil. Once the equilibrium between soil matric potential and the applied air pressure was attained, the soil samples were removed from the pressure plate, weighed and oven dried for gravimetric determination of water content. The cells were disconnected from the air pressure source and weighed to determine the change in mass, and thus water content from the previous step. Cells were then reconnected to the air pressure and a new higher pressure step was applied. Using RETC software, van Genuchten soil water retention function was fitted to the soil water content and pressure head data in order to determine the van Genuchten parameters $(\alpha$ and $n$ ). The values of $m$ and $n$ are presented in table 1 .

\subsection{Bacteria}

Escherichia coli BL21 was used for the microbial transport studies. Bacterial suspension was prepared by taking a needle scoop of $E$. coli and mixing it with $100 \mathrm{~mL}$ of Luria Bertani broth. The mixture was shaken for $24 \mathrm{~h}$ at $37^{\circ} \mathrm{C}$. Bacterial concentration in the resulting cell suspension was enumerated by plate count on Tryptone Bile $\mathrm{X}$-Glucuronide (TBX) agar. The suspension was centrifuged for $10 \mathrm{~min}$ at $8000 \mathrm{rpm}$ and the supernatant was removed and replaced with $10 \mathrm{mM} \mathrm{NaCl}$, followed by centrifugation. These steps were repeated twice to completely remove any trace of growth medium present along with the cell suspension. Electrolyte solutions used in cell suspensions and experiments were prepared with sterile tap water and reagent-grade $\mathrm{NaCl}$ with no $\mathrm{pH}$ adjustment. Different dilutions were made and concentrations were determined using plate count method. The resulting bacterial suspension was diluted to the required concentration and used in the column experiment. For experiments in presence of substrate, $1000 \mathrm{mg} / \mathrm{L}$ of glucose was added to the bacterial suspension. In the transport experiments with metabolically inactive bacterial cells, the cells were treated with $4 \%$ para-formaldehyde solution to make them inactive [8]. 


\subsection{Bacterial cell characterization}

To better understand the mechanisms governing the bacterial transport in porous media, characterization of $E$. coli was carried out. To determine the size of the bacterial cells, images of $E$. coli cells, suspended in $10 \mathrm{mM} \mathrm{NaCl}$ at an approximate concentration of $1 \times 10^{5}$ cells $/ \mathrm{mL}$, were taken by a scanning electron microscope (Quanta 200 FEG) operating in high-vacuum mode.

Hydrophobicity analysis of E. coli was conducted using the microbial adhesion to hydrocarbons (MATH) test as described by Rosenberg et al [30]. The optical density of the bacterial suspension was measured at $540 \mathrm{~nm}$ and adjusted to an optical density of $\mathrm{A}_{540}=1.0$. One millilitre of the bacterial suspension was added to $1 \mathrm{~mL}$ of each of xylene, $\mathrm{n}$-hexadecane and chloroform and then vortexed for $30 \mathrm{~s}$. After phase separation (30 $\mathrm{min})$, the optical density of the aqueous phase was again measured and compared with the initial value. Hydrophobicity was calculated according to the following equation:

$$
\begin{gathered}
\% \text { hydrophobicity }=[(\text { A540 initial }- \text { A540 aqueous phase }) / \\
\text { A540 initial }] \times 100
\end{gathered}
$$

Polysaccharide determination of E. coli was carried out by phenol-sulphuric method described by Dubois et al [31]. A sample of $4 \mathrm{~mL}$ was taken in a round tube and $2 \mathrm{~mL}$ of $5 \%$ phenol solution in demineralized water was added. After mixing, $10 \mathrm{~mL}$ of $95 \%$ sulphuric acid was added in a spout in order to get a proper mixing. Thereafter, the mixture was stored for $10 \mathrm{~min}$ at room temperature, mixed again and incubated for $30 \mathrm{~min}$ at room temperature. Adsorption was measured in a 4-cm cuvette at a wavelength of $487 \mathrm{~nm}$ with a UV-Vis spectrophotometer (Techcom, UK) against a reference sample of demineralized water. Samples were analysed twice and the mean value was calculated. The amount of polysaccharides was expressed in $\mathrm{mg} / \mathrm{L}$.

\subsection{Batch kinetic study}

Batch kinetic experiments were performed to evaluate biokinetic parameters and rate constants. Conical flasks of $250 \mathrm{~mL}$ capacity were used for the batch study. As much as $100 \mathrm{~mL}$ of sterilized water was taken in each conical flask and autoclaved properly before the inoculation of the bacterial culture. Then the flasks were inoculated with $1 \mathrm{~mL}$ of bacterial suspension of concentration $140 \mathrm{cfu} / \mathrm{mL}$. One gram per litre of glucose was added to that suspension. Five millilitre of sample was withdrawn from each conical flask at every hour. Two millilitre of sample was subjected to centrifuging in order to remove microbes. Supernatant was then utilized for TOC analysis. Remaining sample was diluted and bacterial concentration was determined using plate count in TBX agar. Batch studies were conducted in aerobic condition. All studies were conducted in triplicate and the average value is reported.

In order to determine the decay constant for the microbial culture, experiments were carried out in conical flasks of $250 \mathrm{~mL}$ capacity. As much as $140 \mathrm{~mL}$ of minimal salt medium (MSM) was taken in each conical flask and the contents were autoclaved before inoculation of the bacterial culture. The composition of MSM was as follows (quantities of chemicals are given in $\mathrm{g} / \mathrm{L}$ in parentheses): $\mathrm{K}_{2} \mathrm{HPO}_{4}$ (0.8), $\mathrm{KH}_{2} \mathrm{PO}_{4}(0.2), \mathrm{CaSO}_{4} \cdot 2 \mathrm{H}_{2} \mathrm{O}(0.05), \mathrm{MgSO}_{4}-7 \mathrm{H}_{2} \mathrm{O}$ (0.5), $\left(\mathrm{NH}_{4}\right)_{2} \mathrm{SO}_{4}(1.0), \mathrm{FeSO}_{4}(0.01)$ and trace element solution $(1 \mathrm{~mL} / \mathrm{L})$ in distilled water [32]. Trace element solution contains: EDTA (0.5), $\mathrm{H}_{3} \mathrm{BO}_{3}(0.3), \mathrm{MnCl}_{2} \cdot 4 \mathrm{H}_{2} \mathrm{O}$ (0.03), $\mathrm{CoCl}_{2} \cdot 6 \mathrm{H}_{2} \mathrm{O}(0.2), \mathrm{ZnSO}_{4} \cdot 7 \mathrm{H}_{2} \mathrm{O}(0.1), \mathrm{Na}_{2} \mathrm{MoO}_{4-}$ $2 \mathrm{H}_{2} \mathrm{O}(0.03), \mathrm{NiCl}_{2} \cdot 6 \mathrm{H}_{2} \mathrm{O}(0.02)$ and $\mathrm{CuCl}_{2} \cdot 2 \mathrm{H}_{2} \mathrm{O}(0.01)$. After the addition of all the salts, $\mathrm{pH}$ of the MSM was 6.7. Then the flasks were inoculated with a $1 \mathrm{~mL}$ bacterial suspension of concentration $100 \mathrm{cfu} / \mathrm{mL}$. A total of $5 \mathrm{~mL}$ of sample was withdrawn from each conical flask at 1-h interval and was diluted and was enumerated using plate count in TBX agar.

\subsection{Batch study for attachment}

Batch equilibrium studies for metabolically active and inactive bacterial cells were conducted to estimate the attachment co-efficient on sand and soil as described by Somasundaram et al [33]. As the bacteria are colloidal in nature, adsorption may not be the correct terminology. Attachment kinetic study was conducted in reaction bottles, using $5 \mathrm{~g}$ of sterilized sand and $50 \mathrm{~mL}$ of bacterial suspension having a concentration $1000 \mathrm{cfu} / \mathrm{mL}$. Reaction bottles were kept in a shaker at $140 \mathrm{rpm}$. Samples were withdrawn at 10, 30, 60, 120, 180 and $360 \mathrm{~min}$ on a selfsacrificing mode. Samples were centrifuged and analysed for residual bacterial concentration. The equilibrium time obtained from the kinetic study was used for equilibrium studies. The amount of sand/soil was varied from 2 to $6 \mathrm{~g}$ $(2,3,4,5$ and $6 \mathrm{~g})$ in equilibrium studies. Bacterial concentration $(1000 \mathrm{cfu} / \mathrm{mL})$ was same in each reaction bottle. Reaction bottles were kept in a shaker for $3 \mathrm{~h}$ (pseudoequilibrium time) at $140 \mathrm{rpm}$. At the end of $3 \mathrm{~h}$, the supernatant was separated and analysed for residual bacterial concentration. It may be noted that decay and growth have not been considered during the experimental period. It is expected that these were negligible because a substrate was not added and all the experiments were conducted in MSM.

\subsection{Continuous column study}

Column experiments were performed in a plexi-glass column of $40 \mathrm{~cm}$ length and $3.45 \mathrm{~cm}$ diameter. Column was wet packed with sand/soil to get a uniform packing without 


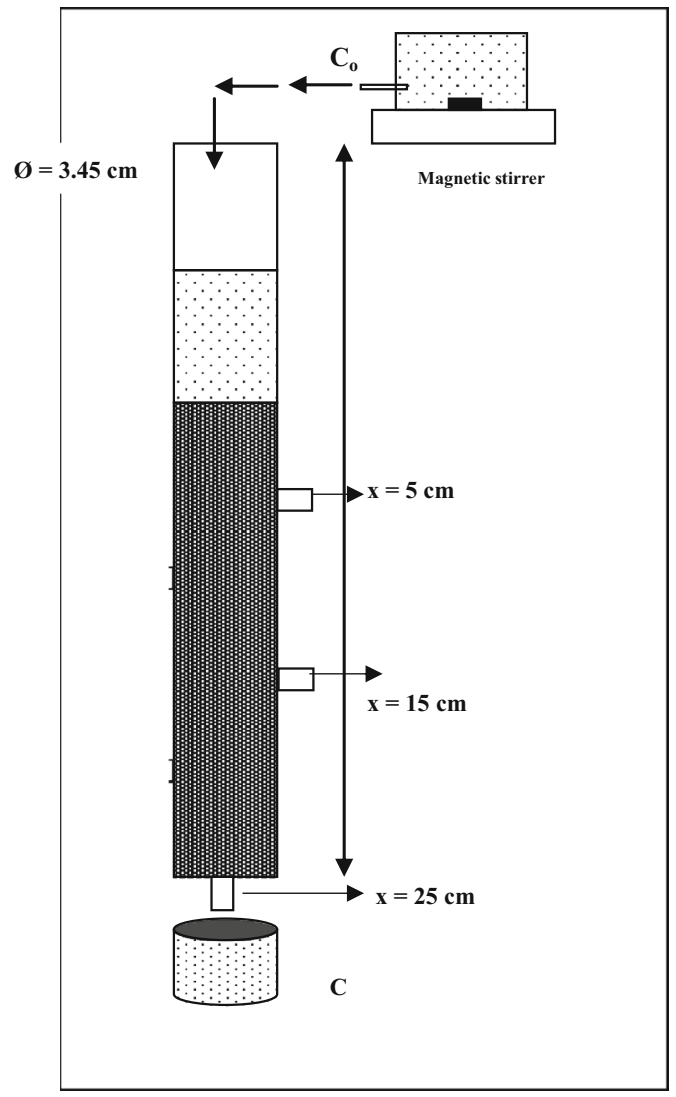

Figure 1. Schematic diagram of column used for experimental studies.

the formation of stratifying layers and preferential flow paths. A water depth of approximately $5 \mathrm{~cm}$ was maintained on the top of soil/sand column to ensure saturated conditions in the column and maintain a constant inlet pressure. The schematic of the experimental set-up is presented in figure 1 . Porosity of the packing medium was estimated using volume displacement method. Constant head was maintained in the inlet tank to obtain steady flow rate through the column. The flow rate variation with time was monitored by collecting the water at the outlet. A collection beaker was placed at the outlet. Once the steadyflow condition was attained, the cell suspension was introduced into the system through the inlet tank at a required flow rate. Sampling ports were provided on the sides at three different cross sections, at distances 5, 15 and $25 \mathrm{~cm}$ from the inlet. Liquid samples were collected from these ports at specified time intervals using a syringe. They were then enumerated using plate count in TBX agar. The metabolically inactive cells were quantified using the standard Lowry method of protein estimation [34]. Substrate concentrations were determined using TOC analyser. Fresh bacterial suspension and a newly packed column were used for each transport experiment. A summary of the experimental conditions is given in table 2 .

For the transient unsaturated flow experiments, dry sand/soil was slowly added to the column in $1-\mathrm{cm}$ increments while being stirred and gently tapped to avoid air entrapment and to ensure uniform packing. To allow a chemical equilibration of the sand pack with the background solution, the packed columns were flushed with $10 \mathrm{mM}$ NACL, followed by MSM solution prior to each experiment. The column was then drained and the infiltration experiment was initiated by dripping the input solution onto the upper sand/soil surface at a constant infiltration rate. The background solution used for column experiments was MSM solution whose composition has been given earlier. MSM were sterilized at $121^{\circ} \mathrm{C}$ for $15 \mathrm{~min}$ before use. The $\mathrm{pH}$ of the medium was maintained at 6.7. The bacterial culture was centrifuged for $10 \mathrm{~min}$ at $8000 \mathrm{rpm}$ and the supernatant was removed and replaced with $10 \mathrm{mM}$ $\mathrm{NaCl}$ followed by centrifugation. The cells were again resuspended in $10 \mathrm{mM} \mathrm{NaCl}$ solution. As much as $10 \mathrm{~mL}$ of this solution was transferred to $1 \mathrm{~L}$ of MSM and fed to the column. The initial influent bacterial concentration was $10^{3}$ $\mathrm{CFU} / \mathrm{mL}$ in all the experiments. The saturated hydraulic conductivity of sand and soil were measured to be $34.45 \mathrm{~cm} / \mathrm{h}$ and $28.5 \mathrm{~cm} / \mathrm{h}$. A summary of the experimental conditions are given in table 2 . The rate of flow of the bacterial suspension into the column (table 2) was controlled through a valve. The influent bacterial suspension

Table 2. Experimental conditions in the column.

\begin{tabular}{lcccc}
\hline Experiment & Flow condition & Media & Porosity & Darcy velocity (sat.)/infiltration rate (unsat.) (cm/min) \\
\hline 1. & Saturated flow, live cells without substrate & Sand & 0.4 & $0.0535,0.107,0.214$ \\
2. & Saturated flow, live cells without substrate & Soil & 0.37 & $0.0535,0.107,0.214$ \\
3. & Saturated flow, inactive cells & Sand & 0.4 & 0.107 \\
4. & Saturated flow, inactive cells & Soil & 0.37 & 0.107 \\
5. & Saturated flow, live cells with substrate & Sand & 0.4 & 0.107 \\
6. & Saturated flow, live cells with substrate & Soil & 0.37 & 0.107 \\
7. & Unsaturated flow, live cells without substrate & Sand & 0.4 & 0.27 \\
8. & Unsaturated, live cells without substrate & Soil & 0.36 & 0.22 \\
9. & Unsaturated, inactive cells & Sand & 0.4 & 0.27 \\
10. & Unsaturated, inactive cells & Soil & 0.37 & 0.22 \\
11. & Unsaturated, live cells with substrate & Sand & 0.41 & 0.26 \\
12. & Unsaturated, live cells with substrate & Soil & 0.36 & 0.22
\end{tabular}


was stirred slowly all through the experiment and was kept at atmospheric pressure. The effluent was collected in $10-\mathrm{mL}$ sample tubes at regular time intervals. Samples were collected at the end of the column at definite time intervals (approximately $30 \mathrm{~min}$ in the beginning and then increasing up to $200 \mathrm{~min}$ towards the end of the experiment). To maintain unsaturated condition of the column, a nylon membrane was attached to the base of the sand column to ensure that pore liquids in the sand are in hydraulic contact with liquid within sampling device. A soil moisture meter (Rapitest Lusterleaf Moisture Meter, India) is used to evaluate the wet front in time and space. Water content was measured at $5 \mathrm{~cm}$ and $15 \mathrm{~cm}$ depths of the column using the moisture meter.

\subsection{Mathematical model for saturated flow conditions}

Mathematical model for bacterial transport under saturated flow conditions is based on the following advection-dispersion-reaction equation [35], which considers the attachment, detachment, straining and bacterial growth. The basic assumptions made in deriving the model can be summarized as follows:

1. The flow in the column was one-dimensional.

2. The porous medium was homogeneous, and the porosity remained constant throughout the study period.

3. The model was based on the "macroscopic modelling" of microbiological reactions.

4. The temperature was constant throughout the experimental study time.

5. Bacterial decay was insignificant and only bacterial growth was significant in presence of substrate.

$$
\begin{aligned}
& \frac{\partial C}{\partial t}+V_{p} \frac{\partial C}{\partial x}=\alpha_{L} \cdot V_{p} \frac{\partial^{2} C}{\partial x^{2}}-\frac{\rho_{b}}{\varepsilon} \\
& \left(\frac{\varepsilon}{\rho_{b}} K_{a t t} \cdot V_{p} \cdot C-K_{\operatorname{det}} \cdot S_{a t t}+\frac{\varepsilon}{\rho_{b}} K_{s t r}\left(\frac{d_{50}}{d_{50}+z}\right)^{\beta} \cdot C\right)+\left(\frac{\mathrm{d} C}{\mathrm{~d} t}\right)_{\text {growth }}
\end{aligned}
$$

$$
\begin{gathered}
\frac{\partial S_{a t t}}{\partial t}=\frac{\varepsilon}{\rho_{b}} K_{a t t} \cdot V_{p} \cdot C-K_{\mathrm{det}} \cdot S_{a t t}+\left(\frac{\mathrm{d} S_{a t t}}{\mathrm{~d} t}\right)_{\text {growth }} \\
\frac{\partial S_{\text {str }}}{\partial t}=\frac{\varepsilon}{\rho_{b}} K_{s t r}\left[\frac{d_{50}}{d_{50}+z}\right]^{\beta} \cdot C+\left(\frac{\mathrm{d} S_{\text {str }}}{\mathrm{d} t}\right)_{\text {growth }}
\end{gathered}
$$

where $\mathrm{C}$ is the bacterial concentration $\left[\mathrm{NcL}^{-3}\right], \mathrm{V}_{\mathrm{p}}$ is the pore water velocity $\left[\mathrm{LT}^{-1}\right], \alpha_{\mathrm{L}}$ is the dispersivity [L], $\rho_{b}$ is the bulk density $\left[\mathrm{ML}^{-3}\right] ; \varepsilon$ is the porosity, $S_{\text {att }}$ is the concentration of attached bacteria $\left[\mathrm{NcM}^{-1}\right], S_{\text {str }}$ is the concentration of strained bacteria $\left[\mathrm{NcM}^{-1}\right], K_{\text {att }}$ is the coefficient for attachment $\left[\mathrm{L}^{-1}\right], K_{\text {det }}$ is the coefficient for detachment $\left[\mathrm{T}^{-1}\right]$ and $K_{\text {str }}$ is the coefficient for straining $\left[\mathrm{T}^{-1}\right], \beta$ is the an empirical parameter which describes the decrease in straining with depth and $\mathrm{z}$ is the distance from the inlet [L]. The second term on the right-hand side of Eq. (2) represents the net rate of transfer of bacteria from aqueous phase to attached/strained phase. $\alpha_{\mathrm{L}}, K_{\mathrm{att}} \cdot K_{\mathrm{det}} \cdot K_{\mathrm{str}}$ and $\beta$ are the model parameters, and were usually determined through fitting the model to experimental data. The transport equation for substrate considered advection, dispersion and consumption by the bacteria.

$$
\frac{\partial S_{s u b}}{\partial t}+V_{p} \frac{\partial S_{\text {sub }}}{\partial x}=\alpha_{s u b} \cdot V_{p} \cdot \frac{\partial^{2} S_{s u b}}{\partial x^{2}}-\left(\frac{\mathrm{d} S_{\text {sub }}}{\mathrm{d} t}\right)_{c o n s}
$$

where $S_{\text {sub }}$ is the substrate concentration and $\alpha_{\text {sub }}$ is the dispersivity for substrate. The last term on the right-hand side of Eq. (5) represents the rate of substrate consumption by the suspended, attached and strained bacteria. The Monod's equation was used for predicting the bacterial growth as shown in Eq. (6). It was assumed that the biokinetic parameters were the same irrespective of whether the bacteria was suspended, attached or strained.

$$
\begin{gathered}
\left(\frac{\mathrm{d} C}{\mathrm{~d} t}\right)_{\text {growth }}=\frac{\mu_{\max } C \cdot S_{\text {sub }, s}}{K_{s}+S_{\text {sub }, s}} \\
\left(\frac{\mathrm{d} S_{\text {att }}}{\mathrm{d} t}\right)_{\text {growth }}=\frac{\mu_{\max } S_{\text {att }} \cdot S_{\text {sub }, a t t}}{K_{s}+S_{\text {sub att }}} \\
\left(\frac{\mathrm{d} S_{\text {str }}}{\mathrm{d} t}\right)_{\text {growth }}=\frac{\mu_{\max } S_{\text {str }} \cdot S_{\text {sub }, \text { str }}}{K_{s}+S_{\text {sub }, s t r}}
\end{gathered}
$$

where $\mu_{\max }$ is the maximum specific growth rate, $K_{s}$ is the half saturation constant and $S_{\text {sub,s }}$ is the substrate concentration utilized by the suspended biomass, $S_{\text {sub,att }}$ is the substrate concentration utilized by the attached bacteria and $S_{\text {sub,str }}$ is the substrate concentration utilized by the strained bacteria. In the present model, it was hypothesized that the substrate availabilities for consumption by the suspended, attached and strained bacteria was in the ratio of the respective bacterial concentrations to total biomass concentration.

$$
\begin{gathered}
S_{s u b, s}=S_{\text {sub }} \frac{C}{C+\frac{\rho_{b}}{\varepsilon}\left(S_{a t t}+S_{s t r}\right)} \\
S_{\text {sub }, a t t}=S_{\text {sub }} \frac{\frac{\rho_{b}}{\varepsilon} S_{a t t}}{C+\frac{\rho_{b}}{\varepsilon}\left(S_{a t t}+S_{s t r}\right)} \\
S_{\text {sub }, s t r}=S_{\text {sub }} \frac{\frac{\rho_{b}}{\varepsilon} S_{\text {str }}}{C+\frac{\rho_{b}}{\varepsilon}\left(S_{a t t}+S_{s t r}\right)}
\end{gathered}
$$

Substrate consumption rate was obtained from the bacterial growth rate through the yield coefficient, $\gamma$

$$
\left(\frac{\mathrm{d} S_{\text {sub }}}{\mathrm{d} t}\right)_{\text {cons }}=\frac{1}{\gamma}\left(\left(\frac{\mathrm{d} C}{\mathrm{~d} t}\right)_{\text {growth }}+\frac{\rho_{b}}{\varepsilon}\left(\frac{\mathrm{d} S_{\text {att }}}{\mathrm{d} t}\right)_{\text {growth }}+\frac{\rho_{b}}{\varepsilon}\left(\frac{\mathrm{d} S_{\text {str }}}{\mathrm{d} t}\right)_{\text {growth }}\right)
$$

The governing equations were solved using a finite volume method, with Lax-Friedrichs Essentially Non-Oscillating 
(ENO) scheme for discretization of advection term, central finite-difference scheme for dispersion term and CrankNicholson scheme for time stepping [36]. The discretization for advection-dispersion-reaction equation is as follows:

$$
\begin{aligned}
& \frac{C_{i}^{t+\Delta t}-C_{i}^{t}}{\Delta t}+\frac{0.5}{\Delta x}\left[F_{i+1 / 2}^{t+\Delta t}-F_{i-1 / 2}^{t+\Delta t}\right]+\frac{0.5}{\Delta x}\left[F_{i+1 / 2}^{t}-F_{i-1 / 2}^{t}\right] \\
& =\frac{R_{i}^{t+\Delta t}+R_{i}^{t}}{2.0}
\end{aligned}
$$

where $F$ is the total flux due to both advection and dispersion and $R$ is the reaction terms (terms representing attachment, detachment, straining and bacterial growth). Subscript $i$ indicates the value at the centre of cell $i$, while subscripts $i+1 / 2$ and, $i-1 / 2$ refer to the values at the right and left faces of the cell $i$, respectively. Superscript $t$ indicates the known value at the present time level $t$, superscript $t+\Delta t$ indicates the unknown value at the future time level $t+\Delta t, \Delta t$ is the computational time step and $\Delta x$ is the spatial step. Flux $F$ contains the advective flux, $F_{C}$ and dispersive flux, $F_{D}$. These fluxes at the face $i+1 / 2$ were computed using the following equations.

$$
\begin{gathered}
F_{C, i+1 / 2}=V_{p} \cdot C_{L} \\
F_{D, i+1 / 2}=-\alpha_{L} \cdot V_{p} \cdot\left(\frac{C_{i+1}-C_{i}}{\Delta x}\right)
\end{gathered}
$$

$C_{L}$ is the concentration value at the face determined using the information from the upstream side. Value of $C_{L}$ at the face was obtained using the MUSCL (Monotonic upstream scheme for conservation laws) approach. A slope limiter was used to obtain the $C_{L}$ value from $C_{i}, C_{i-1}$, and $C_{i+1}$ as shown below.

$$
C_{L}=C_{i}+\frac{\delta C_{i}}{2}
$$

There are several ways of determining $\delta C$ using different "slope limiters." Slope limiters are used to suppress unphysical numerical oscillations. The Minmod limiter was used in this study. According to this limiter, $\delta C_{i}$ is given by the following equation.

$$
d C_{i}=\operatorname{Minmod}\left(C_{i+1}-C_{i}, C_{i-} C_{i-1}\right)
$$

The reaction terms were included through the iterative coupling technique. In this procedure, values at the unknown time level $t+\Delta t$ at iteration $k=0$ are assumed to be the same as those at the known time level $t$, as far as the reaction terms were concerned. This makes the discretized transport equation, written for all nodes $i$, a system of linear algebraic equations. This linear system is used to obtain the predicted values of concentration at the unknown time level $t+\Delta t$. These predicted values are then used to update the reaction terms at the unknown time level $t+\Delta t$ and iteration $k=1$, and these iterations are continued until convergence.

Bacterial concentration was constant at the inlet for all transport experiments without the substrate. This constant value is specified as boundary condition. In the case of transport experiment with substrate, the bacterial as well as the substrate concentrations at the inlet varied with time. Measured values of bacterial concentration and the substrate concentration at the inlet were specified as boundary conditions at the inlet for these simulations. A zero concentration gradient boundary condition was specified at the outlet. The boundary conditions were implemented implicitly along with Crank-Nicholson discretization for interior nodes in order to achieve numerical stability. Moreover, the time step $\Delta t$ was chosen such that the Courant Number was less than one.

\subsection{Mathematical model for unsaturated flow conditions}

The HYDRUS-1D software [37] was used for simulating the unsaturated flow experiments. Detailed description of the model is available in [37] and so only relevant aspects of the code are briefly summarized as follows. The code may be used to analyse water and solute movement in unsaturated, partially saturated or fully saturated porous media. In this software, Richards's equation for saturatedunsaturated water flow (Eq. 14) and Fickian-based advection-dispersion equations for solute transport in the liquid phase (Eq. 15) are numerically solved. It is assumed that the air phase has negligible effect on variably saturated flow and that the air pressure varies only little in space and time.

$$
\frac{\partial \theta}{\partial t}=\frac{\partial}{\partial x}\left[K\left(\frac{\partial h}{\partial x}\right)+1\right]-S_{\sin k}
$$

The mass balance equation is defined as

$$
\frac{\partial \theta C}{\partial t}+\rho_{b} \frac{\partial S}{\partial t}=\frac{\partial}{\partial x}\left[\theta D \frac{\partial C}{\partial x}\right]-\frac{\partial q C}{\partial x}
$$

where $\theta$ is the volumetric water content, $t$ is the time [T], $x$ is the spatial coordinate (positive upward) [L], $h$ is the water pressure head [L], $S_{\text {sink }}$ is the sink term $\left[\mathrm{L}^{3} \mathrm{~L}^{-3} \mathrm{~T}^{-1}\right]$, $K$ is the unsaturated hydraulic conductivity function $\left[\mathrm{LT}^{-1}\right], q$ is the flow velocity $\left[\mathrm{LT}^{-1}\right], \mathrm{C}$ is the bacteria concentration in the aqueous phase $\left[\mathrm{NcL}^{-3}\right], \mathrm{S}$ is the solid phase concentration $\left[\mathrm{NcM}^{-1}\right]$ and $\mathrm{NC}$ is the number of bacteria. $K$ is a function of the water pressure head. Volumetric water content is also a function of the water pressure head. In this software, the van Genuchten analytical model for hydraulic properties is employed to obtain predictive equations for the unsaturated hydraulic conductivity and moisture functions in terms of soil water retention parameters. 
The transport equations are formulated in such a way that they can include non-linear and/or non-equilibrium reactions between the solid and liquid phases. The bacterial transport is modelled using a modified form of the advection-dispersion equation (Eq. 13) that includes two-site kinetic attachment-detachment model, which represent kinetic attachment and straining processes. The approach divides the retained bacteria into two fractions and assumes different rates or processes occurring for each deposition site [38]. The first kinetic site employs a conventional attachment and detachment model to describe the mass transfer between the aqueous and the solid phase. Under unsaturated conditions, attachment to the solid phase and air-water interface are lumped in the attachment term and the second kinetic site lumps all depth-dependent mass transfer processes from aqueous to solid phase [38]. The governing flow and transport equations are numerically solved using the Galerkin finite element scheme. Integration in time is achieved using implicit (backward and Crank-Nicholson) finite difference schemes. Boundary conditions for bacterial and substrate concentration were same as those described in case of saturated flow conditions. Measured inflow rate was specified as boundary condition at the inlet while solving the flow equations. Free drainage boundary condition was applied at the outlet for flow equations.

\section{Results and discussion}

\subsection{Batch studies for attachment}

Kinetic studies were conducted to understand the role of attachment on the transport of bacteria in aquifers. Kinetics of attachment of live and metabolically inactive bacterial cells on sand and soil were studied using batch experiments. Attachment was very fast during the initial few minutes and attained a pseudo-equilibrium state within $1 \mathrm{~h}$ for both live and inactive cells in sand, and within $2 \mathrm{~h}$ for live and inactive cells in soil. The rapid achievement of attachment equilibrium is consistent with results reported by Guber et al [39] and Nola et al [40] using sand and soil. This equilibrium time was used in further studies. Attachment under equilibrium conditions followed the Freundlich model like behaviour. Table 3 shows the Freundlich coefficient $\left(K_{\mathrm{f}}\right)$, exponent $(1 / \mathrm{n})$ and the corresponding correlation coefficients for all the equilibrium equations. It can be seen that attachment of bacteria is higher in soil than in sand. This is due to higher clay and organic contents in soil. Similar observations have been reported by Guzman et al [41]. The Freundlich coefficient $K_{f}$ for attachment of live cells to the sand and soil was higher than that for the sorption of inactive cells. In this context, study of the hydrophobicity of bacteria helps in understanding the role of hydrophobic interactions in microbial adhesion. In the present study, hydrophobicities of live and inactive bacteria
Table 3. Freundlich attachment constants for live and inactive bacterial cells on soil and sand.

\begin{tabular}{lllc}
\hline & \multicolumn{3}{c}{ Freundlich constants } \\
\cline { 2 - 4 } Nature of cells & $K_{\mathrm{f}}$ & $K_{\mathrm{e}}$ & $R^{2}$ \\
\hline Live cells in sand & 0.2 & 2.6 & 0.99 \\
Inactive cells in sand & 0.06 & 1.5 & 0.99 \\
Live cells in soil & 0.8 & 2.7 & 0.98 \\
Inactive cells in soil & 0.12 & 1.8 & 0.99 \\
\hline
\end{tabular}

were found to be $50.2 \%$ and $41.7 \%$, respectively. Similar observation has been reported by Zhong et al [42]. It was reported that a decrease in cell hydrophobicity could reduce the attachment of bacterial cells to the porous media. In case of live cells, significant hydrophobic interactions might have led to the reduction in energy barrier between the bacteria and the grain surface, causing increase in attachment.

\subsection{Cell characterization}

The bacterial species used in the present study was Gram negative, which emanates extracellular polymeric substance (EPS), a mixture of polysaccharides, nucleic acids and proteins. The zeta potentials of active and inactive cells were found to be $-14.2 \mathrm{mV}$ and $-17.7 \mathrm{mV}$ at an ionic strength of $154 \mathrm{mM}$. Charge reversal of the bacteria occurs at higher ionic strength as the counter-ions increase near the cell surface and are present amidst the outermost EPS structure of the cell [20]. The sand and soil were also negatively charged at the prevailing experimental conditions. Therefore, the effect of electrostatic repulsion was stronger, resulting in changes in the transport phenomenon. Also, the measured charged densities of the inactive and active cell $\left(806\right.$ and $712 \mu \mathrm{C} / \mathrm{cm}^{2}$ ) from the potentiometric titration experiments are consistent with the zeta potential values. The MATH analysis established that $50.2 \%$ and $41.7 \%$ of cells in $154 \mathrm{mM} \mathrm{NaCl}$ solution partitioned onto xylene, n-hexadecane and chloroform for active and inactive cells, respectively. These values clearly indicate that the active cells are more hydrophobic than the inactive bacteria. The bacterial cell wall structure influences the bacterial attachment to porous media. Escherichia coli, being Gram-negative bacteria, have an outer lipid bilayer exterior to the cell wall, which contains lipopolysaccharide (LPS) and proteins. The presence of this layer was reconfirmed from the electrophoretic mobility and potentiometric titration measurements. Influent samples of metabolically active and inactive bacterial suspensions were analysed for LPS using the phenol-sulphuric acid method [31]. The LPS of live cell (1.635) was found to be higher than the LPS of inactive cell (0.924). These macromolecules, integrated with the surface of the cell, could get off the medium and 
can also have an effect on the transport of bio-colloids in porous media [43].

\subsection{Biokinetic parameters}

Biokinetic parameters were estimated from batch kinetic study. The batch study was conducted in aerobic condition and the results are presented in figure $2 \mathrm{a}$. The maximum specific growth rate, $\mu_{\max }(0.64 / \mathrm{h})$ and yield co-efficient, $\gamma$ (0.24) found in the present study fall within the range of $0.53-0.76 / \mathrm{h}$ and $0.23-0.26$ as reported by Poccia et al [43]. The decay kinetics of $E$. coli is shown in figure $2 b$. The decay constant, $K_{\text {decay }}$, was found to be $0.25 /$ d, which is in the range of reported values of $0.1 / \mathrm{d}-0.25 / \mathrm{d}$ [44]. $K_{\mathrm{s}}$ value was found to be $50 \mathrm{mg} / \mathrm{L}$, which falls within the broad range of values of $40 \mu \mathrm{g} / \mathrm{L}$ to $99 \mathrm{mg} / \mathrm{L}$ reported by Senn et al [45].

\subsection{Transport in saturated porous media}

Transport experiments were conducted to depict the bacterial movement during leakage from any on-site wastewater treatment system such as a septic tank. In such

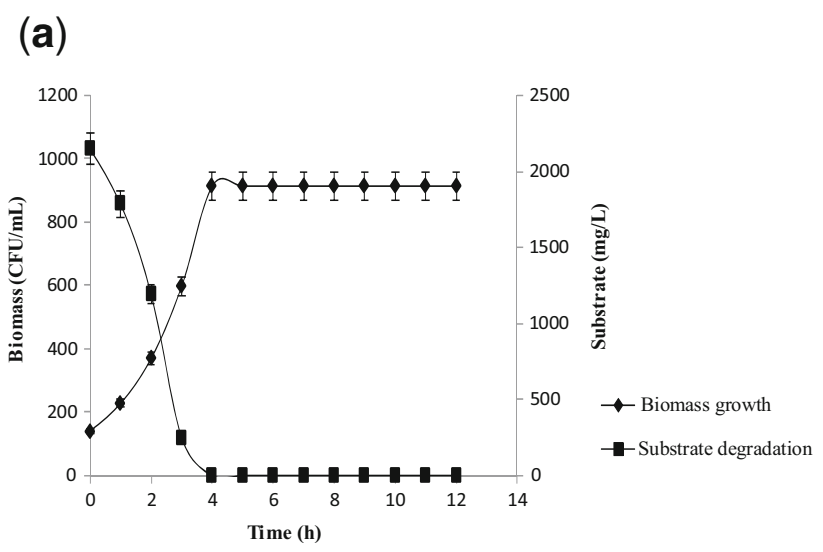

(b)

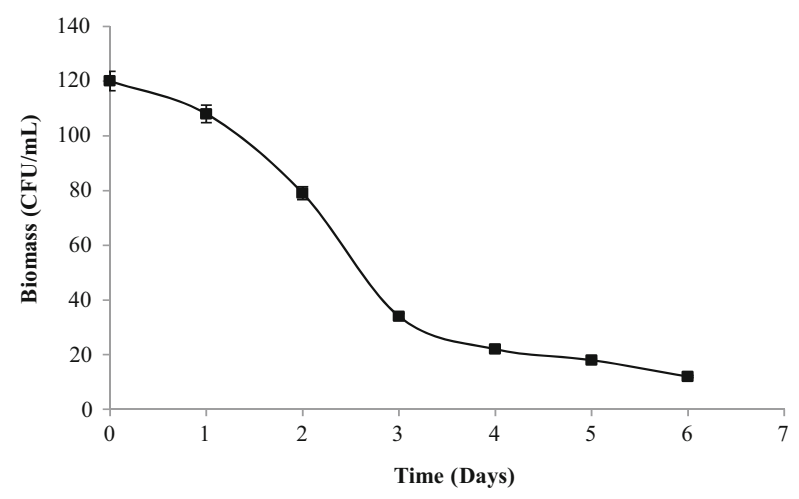

Figure 2. Bio-kinetics of growth and decay of E. coli. (a) Growth kinetics of bacteria and glucose reduction by E. coli. (b) Decay kinetics of E. coli. situations, either saturated or unsaturated flow conditions can occur. Hence, experiments were conducted for both saturated and unsaturated conditions. Moreover, the bacteria may be moving along with food and other nutrients, depending on the degree of treatment. This section discusses the transport experiments in saturated condition for different scenarios, which include (i) the effect of flow rate, (ii) physiological state, (iii) grain size and (iv) presence of organic matter.

3.4a Transport of metabolically inactive and active cells: Microbiological effects associated with the activity of cells are important in transport studies and are significant for many practical applications. The nature of bacterial cell surface is a function of physiological state of bacteria. Growth phase influences the cell surface hydrophobicity and electrophoretic mobility. The macromolecular composition of bacterial cell surface plays an important role in the surface hydrophobicity, adhesive properties, and in the formation of aggregates [8]. Usually, colloidal inert particles are used in experiments to depict the bacterial movement. Experiments conducted with both active and inactive cells bring out the variations caused due to inactivity.

Experimental results for transport of metabolically active and inactive bacteria (flow rate $=1.0 \mathrm{~mL} / \mathrm{min}$ ) in sand are shown in figure $3 \mathrm{a}$ and $\mathrm{b}$, respectively. While conducting experiments in sand columns without substrate, peak breakthrough concentrations for metabolically active and inactive cells were found to be 0.68 and 0.75 , respectively. It can be seen that inactive cells travel faster (i.e., higher breakthrough concentration) than live cells. As mentioned earlier, hydrophobicities of live and inactive bacteria were found to be $50.2 \%$ and $41.7 \%$, respectively. The more hydrophobic live bacteria exhibited more affinity to the hydrophilic sand. These results are in agreement with other observations reported in the literature. It has been reported that starvation decreased hydrophobicity of bacteria and increased their mobility [46]. The bacterial cell wall structure influences the bacterial attachment to porous media. Cell size and shape may also play a role in transport and deposition through the porous media [47]. Inactive cells are morphologically different from live cells, as shown in figure ESM_3a and ESM_3(b in electronic supplementary material. The average length and width of metabolically active $E$. coli were found to be $1.575 \pm 0.12 \mu \mathrm{m}$ and $606.35 \pm 0.01 \mathrm{~nm}$, respectively. The inactive cell appears to be slightly elongated than a live cell with the average length and width of $2.07 \pm 0.12 \mu \mathrm{m}$ and $582 \pm 0.01 \mathrm{~nm}$, respectively. These results clearly indicate that smaller size of inactive cells may also contribute to their faster movement as compared to the live cells.

Peak breakthrough concentrations for metabolically active and inactive cells in soil media were found to be 0.55 and 0.62 , as shown in figure $3 c$ and $d$, respectively. The breakthrough concentrations of live and inactive cells in soil were lesser than the breakthrough concentrations of 
(a)

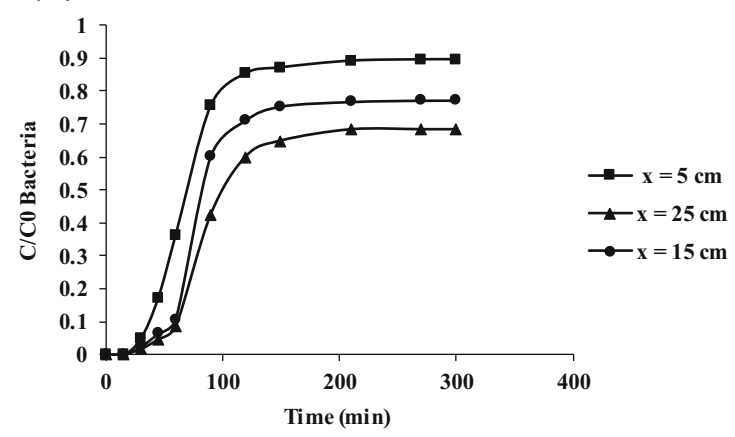

(b)

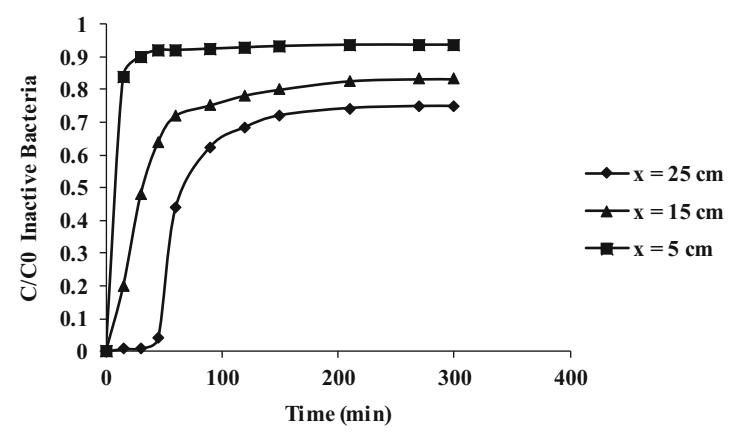

(c)

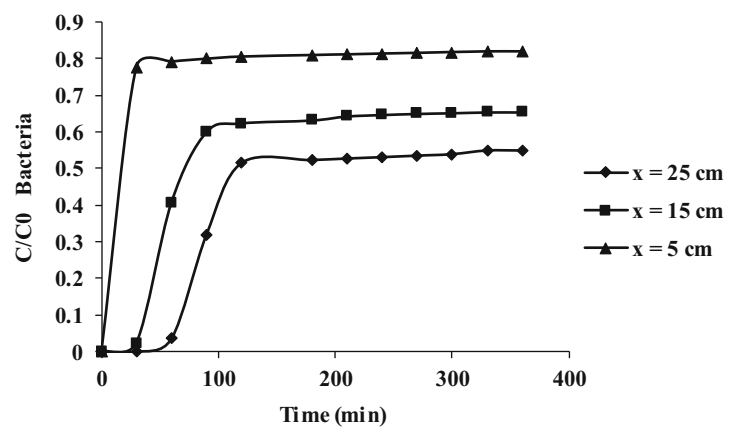

(d)

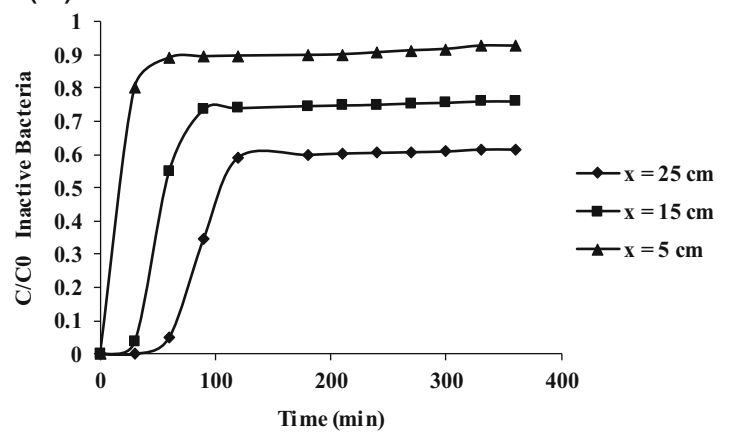

Figure 3. Breakthrough of active cells and inactive cells for flow rate of $1 \mathrm{~mL} / \mathrm{min}$. (a) Transport of active bacteria in saturated sand media, (b) Transport of inactive bacteria in saturated sand media, (c) Transport of active bacteria in saturated soil media and (d) Transport of inactive bacteria in saturated soil media.

live and inactive cells in sand. As expected, this may be due to the high clay and organic content, which cause more adhesion in soil. It may be also because of more straining caused by smaller pore size. The median grain size of sand was $400 \mu \mathrm{m}$, while that of soil was $320 \mu \mathrm{m}$. Another interesting observation was that the difference in the breakthrough concentration between active and inactive cells was of the same order of magnitude for both sand $(0.75-0.68)$ and soil $(0.62-0.55)$.

Experimental data for the flow rate of $1.0 \mathrm{~mL} / \mathrm{min}$ at $x=25 \mathrm{~cm}$ were used in the mathematical model (section 2.8) to estimate the transport parameters such as $\alpha_{\mathrm{L}}, K_{\text {att }}$. $K_{\text {det }} . K_{\text {str }}$ and $\beta$ for the transport of both active and inactive cells. The fitting procedure minimized the sum of the squares of differences between simulated and observed concentrations. Figure $4 \mathrm{a}$ shows the comparison between the simulated (using the fitted parameters) and observed variation in bacterial concentration at $x=25 \mathrm{~cm}$, for the case of transport of live cells in soil and sand, respectively. Results for temporal variation in bacterial concentration at $x=5 \mathrm{~cm}$ and $x=15 \mathrm{~cm}$ (validation) are presented in electronic supplementary material (ESM_4(a) and ESM_4(b)). It can be observed from these figures that the matching between simulated and observed results is satisfactory in almost all cases except for the case of breakthrough at $x=5 \mathrm{~cm}$ in sand column, where observed breakthrough significantly lagged behind the simulated breakthrough. However, simulated breakthrough compared well with observed breakthrough at longer distances from the inlet, that is, at $x=15 \mathrm{~cm}$ and $x=25 \mathrm{~cm}$. The matching between the simulated and observed values may be quantified statistically using either the $\mathrm{R}^{2}$ value or the Modified Coefficient of Efficiency, E. These values are presented in table 4. E values equal to 1.0 indicate perfect agreement, while $\mathrm{E}$ values greater than 0.5 indicate good fit. Figure $4 \mathrm{~b}$ shows the comparison between the simulated (using the fitted parameters) and observed variation in bacterial concentration at $x=25 \mathrm{~cm}$, for the case of transport of inactive cells in soil and sand, respectively. Mathematical model results for other locations i.e. at $x=5 \mathrm{~cm}$ and $x=15 \mathrm{~cm}$ (validation) are presented in the electronic supplementary material (ESM_5(a) and ESM_5(b)). It can be observed from these figures that the matching between the simulated and observed results is satisfactory in all the cases. Results presented here corroborate the fact that a mathematical model based on attachment, detachment and straining concepts can be used for simulating the transport of bacteria in saturated sand and soil media.

The transport parameters which were determined using the fitting procedure are shown in table 5 . It can be seen from table 5 that the coefficients for attachment and straining, $K_{\text {att }}$ and $K_{\text {str }}$ are larger for metabolically active 
(a)

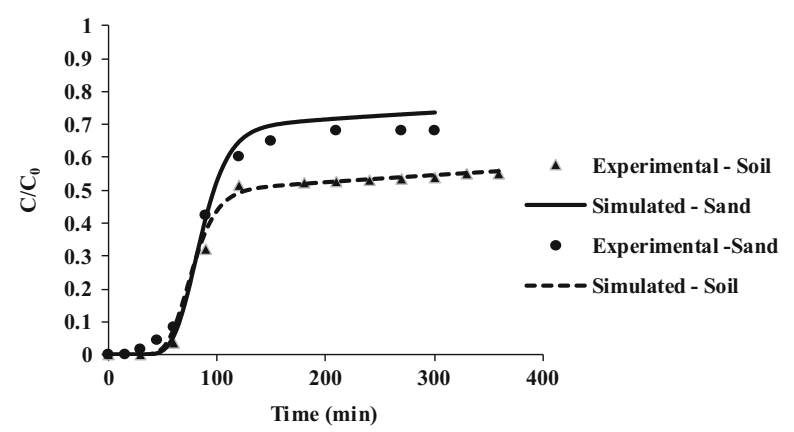

(b)

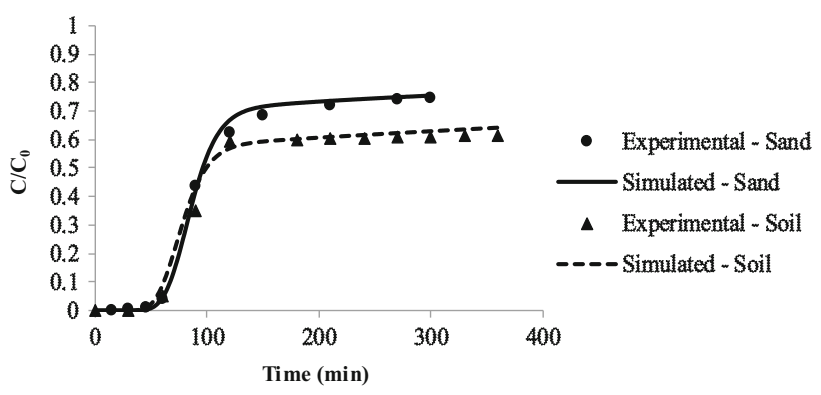

Figure 4. Comparison of simulated and experimental breakthroughs for flow rate of $1 \mathrm{~mL} / \mathrm{min}$. (a) Transport of active cells in saturated sand and soil media. (b) Transport of inactive cells in saturated sand and soil media.

bacteria than those for inactive bacteria. On the other hand, coefficient for detachment, $K_{\text {det }}$, is larger in the case of inactive cells. Same is true in the case of soil also. These results also indicate that bacteria are more mobile and could transport to longer distances when they are in an inactive state as compared to when they are in an active state. It can also be observed that attachment and straining coefficients are larger in the case of soil medium than in the case of sand medium. Obviously, soil acts as a better filter medium than the sand because of smaller grain size and higher organic and clay content. Another important observation from the mathematical model simulations is that the coefficient $\beta$ is not equal to zero. As the model by Bradford et al [35] postulates, the rate of straining decreased as the distance increased from the inlet.

3.4b Effect of flow rate on transport of bacteria: Transport experiments for metabolically active cells were conducted at different flow rates. Results from these experiments are presented in figure 5a-f. Velocities typically range from few $\mathrm{mm} / \mathrm{d}$ to $\mathrm{m} /$ day in aquifers [48]. Experiments were conducted with three different velocities: $0.0535 \mathrm{~cm} / \mathrm{h}$, $0.107 \mathrm{~cm} / \mathrm{h}$ and $0.214 \mathrm{~cm} / \mathrm{h}$. Peak values of $\mathrm{C} / \mathrm{C}_{0}$ at the exit for experiments in sand column with velocities $0.0535 \mathrm{~cm} /$ h $(0.5 \mathrm{~mL} / \mathrm{min}), 0.107 \mathrm{~cm} / \mathrm{h}(1 \mathrm{~mL} / \mathrm{min})$ and $0.214 \mathrm{~cm} / \mathrm{h}$ ( $2 \mathrm{~mL} / \mathrm{min}$ ) were found to be $0.61,0.68$ and 0.79 , respectively. It was observed that as the velocity increased, the peak concentration at the exit increased. This is in accordance with colloid filtration theory, which states that increasing the flow velocity decreases the retention of colloids in the porous media [35]. A comparison of bacterial transport in sand and soil is useful for evaluating the influence of collector grain properties on the transport process. Peak $\mathrm{C} / \mathrm{C}_{0}$ values at the exit in soil columns were $0.50,0.55$ and 0.60 , corresponding to velocities of $0.0535 \mathrm{~cm} / \mathrm{h}, 0.107 \mathrm{~cm} / \mathrm{h}$ and $0.214 \mathrm{~cm} / \mathrm{h}$, respectively. These relative concentrations were found to be lower than those in the sand column.

The aforementioned experimental data corresponding to flow rates of $2.0 \mathrm{~mL} / \mathrm{min}$ and $0.5 \mathrm{~mL} / \mathrm{min}$ were used in the mathematical model to estimate transport parameters $K_{\text {att }}$. $K_{\text {det }}, K_{\text {str, }}$ and $\beta$. The dispersivity value, $\alpha_{\mathrm{L}}$ was kept the same as that for the case of flow rate equal to $1.0 \mathrm{~mL} / \mathrm{min}$. Estimated values of $K_{\mathrm{att}} . K_{\mathrm{det}}, K_{\mathrm{str}}$, and $\beta$ corresponding to different flow rates are presented in table 6 . It can be observed from this table that there is a marginal decrease in the value of $K_{\text {att }}(4.4 \%)$ as flow rate increased from $0.5 \mathrm{~mL} /$ min to $2 \mathrm{~mL} / \mathrm{min}$ (four-fold increase) in the case of sand column. For the velocities considered here, changes in other

Table 4. $R^{2}$ and E-values for saturated column experiments.

\begin{tabular}{|c|c|c|c|c|c|c|c|}
\hline \multirow[b]{2}{*}{ No } & \multirow{2}{*}{$\begin{array}{l}\text { Experiment } \\
\text { Sand media }\end{array}$} & \multicolumn{3}{|c|}{$R^{2}$} & \multicolumn{3}{|c|}{ E-value } \\
\hline & & $x=5 \mathrm{~cm}$ & $x=15 \mathrm{~cm}$ & $x=25 \mathrm{~cm}$ & $x=5 \mathrm{~cm}$ & $x=15 \mathrm{~cm}$ & $x=25 \mathrm{~cm}$ \\
\hline 1 & Live, $1 \mathrm{~mL} / \mathrm{min}$ & 0.43 & 0.88 & 0.99 & 0.55 & 0.80 & 0.92 \\
\hline 2 & Live, $2 \mathrm{~mL} / \mathrm{min}$ & 0.96 & 0.92 & 0.89 & 0.94 & 0.88 & 0.94 \\
\hline 3 & Live, $0.5 \mathrm{~mL} / \mathrm{min}$ & 0.55 & 0.93 & 0.87 & 0.5 & 0.98 & 0.85 \\
\hline \multirow[t]{2}{*}{4} & Inactive, $1 \mathrm{~mL} / \mathrm{min}$ & 0.99 & 0.95 & 0.87 & 0.99 & 0.95 & 0.87 \\
\hline & Soil media & $x=5 \mathrm{~cm}$ & $x=15 \mathrm{~cm}$ & $x=25 \mathrm{~cm}$ & $x=5 \mathrm{~cm}$ & $x=15 \mathrm{~cm}$ & $x=25 \mathrm{~cm}$ \\
\hline 1 & Live, $1 \mathrm{~mL} / \mathrm{min}$ & 0.99 & 0.99 & 0.99 & 0.98 & 0.97 & 0.97 \\
\hline 2 & Live, $2 \mathrm{~mL} / \mathrm{min}$ & 0.99 & 0.98 & 0.96 & 0.98 & 0.97 & 0.94 \\
\hline 3 & Live, $0.5 \mathrm{~mL} / \mathrm{min}$ & 0.95 & 0.99 & 0.99 & 0.95 & 0.93 & 0.96 \\
\hline 4 & $\begin{array}{c}\text { Inactive, } 1 \mathrm{~mL} / \\
\min \end{array}$ & 0.99 & 0.99 & 0.99 & 0.97 & 0.97 & 0.95 \\
\hline
\end{tabular}


Table 5. Transport parameters from the model in saturated column studies: Flow rate $=1.0 \mathrm{~mL} / \mathrm{min}$.

\begin{tabular}{lcclll}
\hline No & Parameters & $\begin{array}{c}\text { Soil } \\
\text { active }\end{array}$ & $\begin{array}{c}\text { Soil } \\
\text { inactive }\end{array}$ & $\begin{array}{c}\text { Sand } \\
\text { active }\end{array}$ & $\begin{array}{c}\text { Sand } \\
\text { inactive }\end{array}$ \\
\hline 1 & $\begin{array}{c}\text { Dispersivity, } \alpha \\
(\mathrm{cm})\end{array}$ & 0.72 & 0.72 & 0.60 & 0.60 \\
& & & & \\
2 & $K_{\text {att }}\left(\mathrm{cm}^{-1}\right)$ & 0.0187 & 0.015 & 0.00673 & 0.006 \\
3 & $K_{\text {str }}\left(\mathrm{s}^{-1}\right)$ & 0.00043 & 0.00023 & 0.00015 & 0.00012 \\
4 & $K_{\mathrm{d}}\left(\mathrm{s}^{-1}\right)$ & 0.00002 & 0.000023 & 0.00005 & 0.00006 \\
5 & $\beta$ & 0.40 & 0.325 & 0.25 & 0.21 \\
\hline
\end{tabular}

parameters, that is, $K_{\mathrm{str}}, K_{\mathrm{det}}$ and $\beta$, were not appreciable. In the case of soil column experiments, there was a decrease in $K_{\text {att }}$ and $K_{\text {str }}$ of $1.1 \%$ and $4.7 \%$, respectively, as the flow rate

(a)

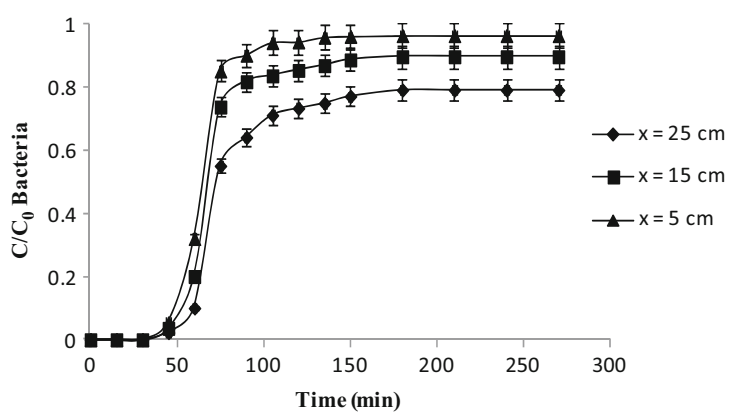

(b)

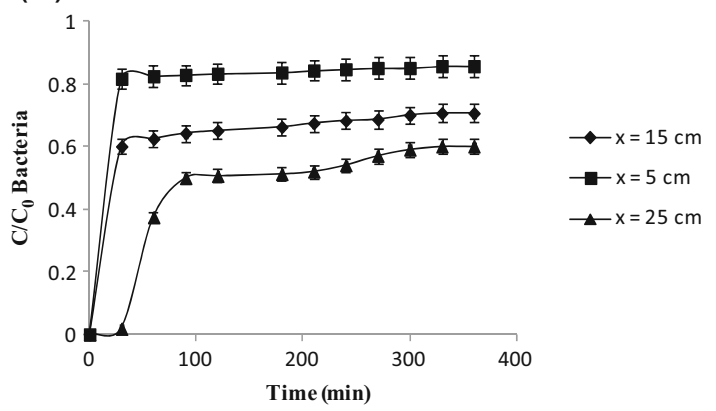

(c)

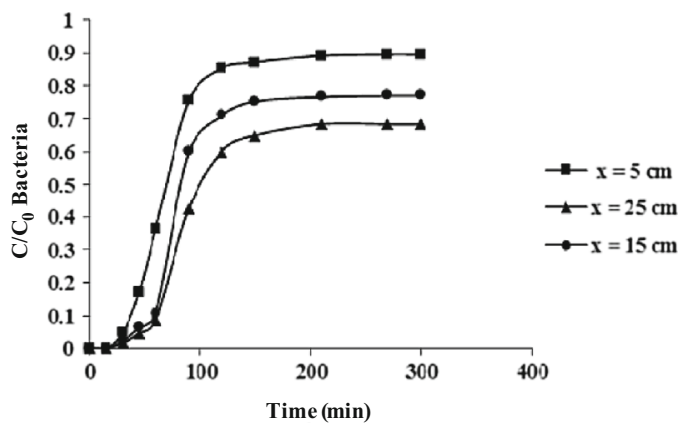

increased from $0.5 \mathrm{~mL} / \mathrm{min}$ to $2 \mathrm{~mL} / \mathrm{min}$. There was no change in the value of $K_{\text {det }}$ in the present experiments. However, there was an appreciable change in the value of $\beta$. The decrease in rate of straining with distance is much higher at lower velocities. Figure 6 shows the comparison between the simulated (using the fitted parameters) and observed variation in bacterial concentration at $x=25 \mathrm{~cm}$, for the case of transport of live cells in soil and sand, respectively, for flow rate of $2.0 \mathrm{~mL} / \mathrm{min}$. Results for temporal variation in bacterial concentration at $x=5 \mathrm{~cm}$ and $x=15 \mathrm{~cm}$, and for flow rate of $\mathrm{Q}=0.5 \mathrm{~mL} / \mathrm{min}$, are presented in electronic supplementary material (ESM_6(a) and ESM_6(b)). It can be observed from these figures that the matching between simulated and observed results is satisfactory in almost all cases except for the case of breakthrough at $x=5 \mathrm{~cm}$ in sand column. However,

(d)

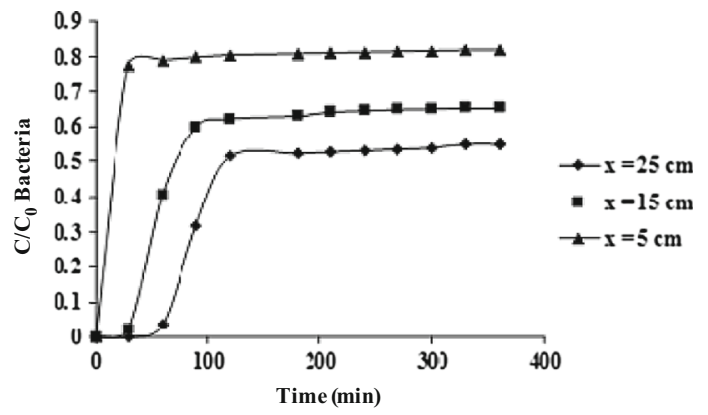

(e)

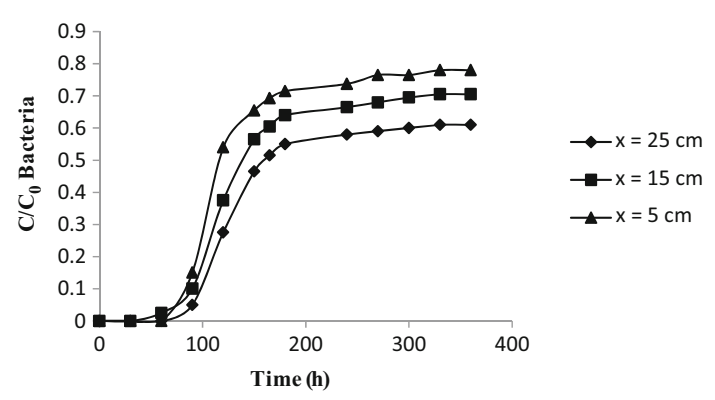

(f)

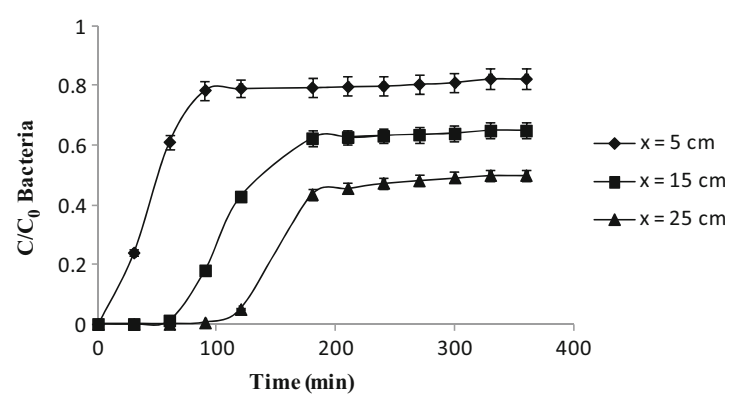

Figure 5. Transport of bacteria in saturated sand and soil porous media for different flow rates (a) Sand column, $2 \mathrm{~mL} / \mathrm{min}$; (b) Soil column, $2 \mathrm{~mL} / \mathrm{min}$; (c) Sand column, $1 \mathrm{~mL} / \mathrm{min}$; (d) Soil column, $1 \mathrm{~mL} / \mathrm{min}$; (e) Sand column, $0.5 \mathrm{~mL} / \mathrm{min}$; (f) Soil column, $0.5 \mathrm{~mL} /$ $\min$. 
Table 6. Transport Parameters from the model in saturated column studies for low $(0.5 \mathrm{~mL} / \mathrm{min})$ and high flow $(2.0 \mathrm{~mL} / \mathrm{min}) \mathrm{rates}$.

\begin{tabular}{cccccc}
\hline No & Parameters & $\begin{array}{c}\text { Sand active flow: } 0.5 \mathrm{~mL} / \\
\min \end{array}$ & $\begin{array}{c}\text { Sand active flow: } \\
\min \end{array}$ & $\begin{array}{c}\text { Soil active flow:0.5 mL/ } \\
\text { min }\end{array}$ & $\begin{array}{c}\text { Soil active flow: } 2 \mathrm{~mL} / \\
\mathrm{min}\end{array}$ \\
\hline 1 & $\begin{array}{c}\text { Dispersivity, } \alpha \\
(\mathrm{cm})\end{array}$ & 0.6 & 0.6 & 0.72 & 0.72 \\
2 & $K_{\text {att }}\left(\mathrm{cm}^{-1}\right)$ & 0.00678 & 0.0065 & 0.0187 & 0.0185 \\
3 & $K_{\text {str }}\left(\mathrm{s}^{-1}\right)$ & 0.00015 & 0.00015 & 0.00043 & 0.00041 \\
4 & $K_{\mathrm{d}}\left(\mathrm{s}^{-1}\right)$ & 0.00005 & 0.00005 & 0.00002 & 0.00002 \\
5 & $\beta$ & 0.25 & 0.25 & 0.52 & 0.25 \\
\hline
\end{tabular}

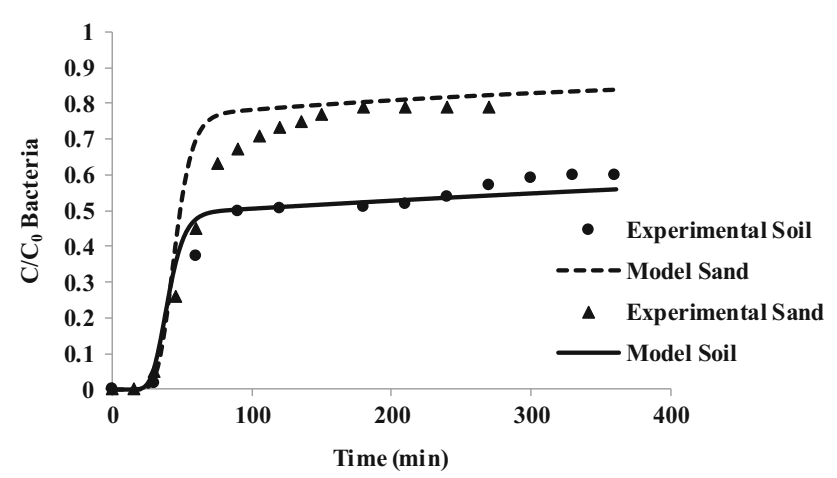

Figure 6. Transport of bacteria in saturated sand and soil media at flow rate $2.0 \mathrm{~mL} / \mathrm{min}$.

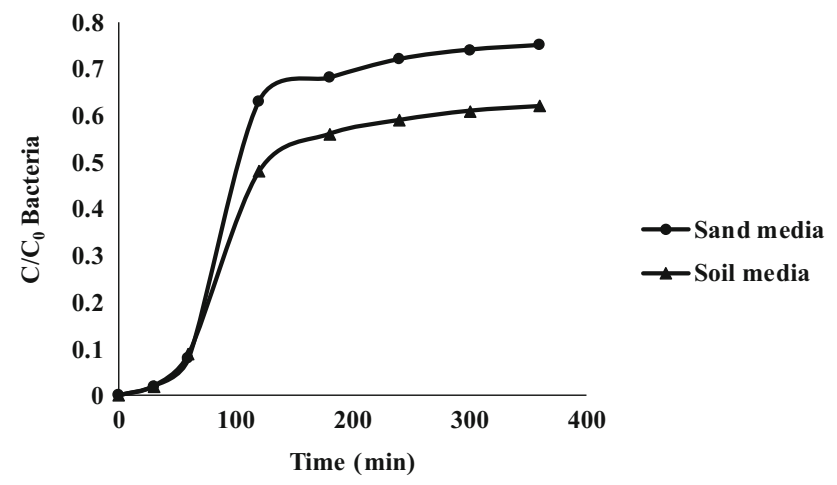

Figure 7. Transport of bacteria with substrate in saturated sand and soil media.

simulated breakthrough compared well with observed breakthrough at longer distances from the inlet, that is, at $x=15 \mathrm{~cm}$ and $x=25 \mathrm{~cm}$, as indicated by $\mathrm{E}$ values $(>0.50)$ presented in table 4 .

3.4c Effect of substrate on transport of bacterial cells: The leakage from septic tanks could provide substrate and nutrients to the environment. This may significantly increase the growth of bacteria and the number. In turn, this could enhance bacterial transport [49] and thus may result in widespread distribution of bacteria in subsurface and contaminate the drinking water wells. As part of present study, experiments were conducted with continuous addition of substrate along with the bacterial suspension. Glucose was used as the substrate for bacteria. Therefore, it was of interest to investigate the transport of substrate alone in the sand and soil media. Complete breakthrough of glucose with peak $C / C_{0}$ value of almost equal to one was observed. It has been observed from the experiments (figure 7) that increase in inlet concentrations resulted in higher breakthrough concentrations at the outlet. Normalized breakthrough concentrations with and without substrate in sand column were found to be 0.75 and 0.68 , respectively. Normalized breakthrough concentrations with and without substrate in soil were found to be 0.62 and 0.55 , respectively. Normalized breakthrough concentrations in soil were less than those observed in case of sand media, as expected. The results obtained indicate that metabolic processes impact the transport of bacteria. Addition of substrate resulted in increase in influent bacterial concentration due to growth. The normalized concentration at the outlet increased from zero at time $t=0\left(\mathrm{C}_{0}=1000 \mathrm{CFU} /\right.$ $\mathrm{mL})$ to an asymptotic value of 0.75 as the time increased and the inlet concentration increased to $64,000 \mathrm{CFU} / \mathrm{mL}$, in case of sand columns. In case of soil columns, the normalized concentration at the outlet increased to a value of 0.62 as the time progressed and the inlet concentration increased to $65,000 \mathrm{CFU} / \mathrm{mL}$. These results are contrary to results obtained earlier by Jansen et al [8]. In their experiments with pulse input, the normalized concentration at the outlet decreased from 0.78 for an inlet bacterial count of $4 \times 10^{7}$ cells to 0.35 for an inlet bacterial count of $10^{9}$ cells. The results from the present study indicate that the loading conditions and the growth of bacteria due to availability of substrate could alter the retention of bacteria significantly.

An attempt was made to simulate the transport of bacteria in presence of substrate by using Monod's equation for bacterial growth. Numerical simulations were based on the transport parameters estimated earlier from experiments without substrate, and the bio-kinetic parameters obtained from batch studies. The simulated results did not match with the experimental data by orders of magnitude. At this stage, it can only be conjectured that the attachment, detachment and straining characteristics get affected by the growth of bacteria. It may be also possible that bio-kinetic parameters in a continuous system may differ from that of batch systems. 
(a)

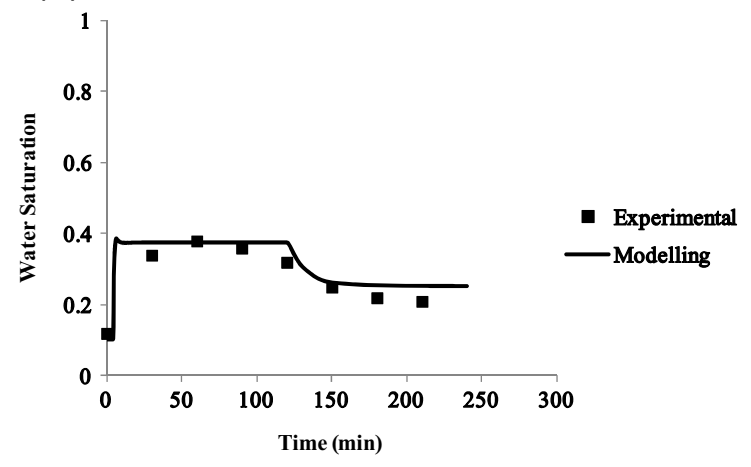

(c)

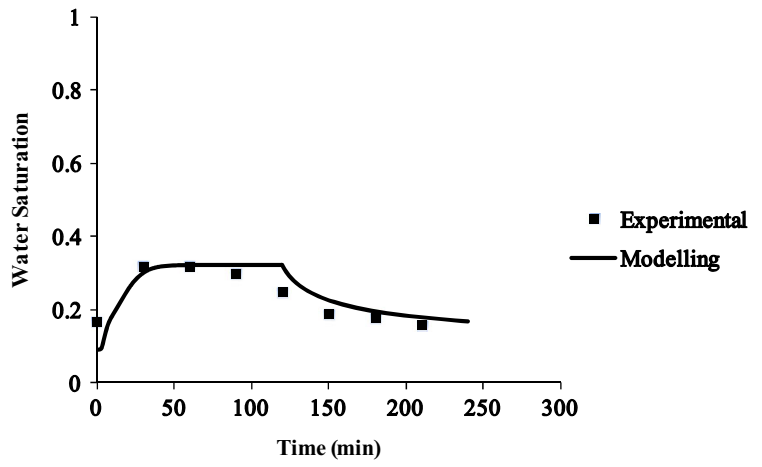

(b)

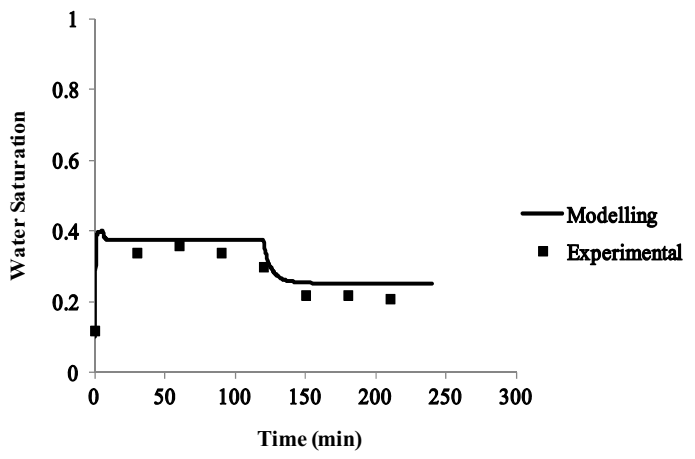

(d)

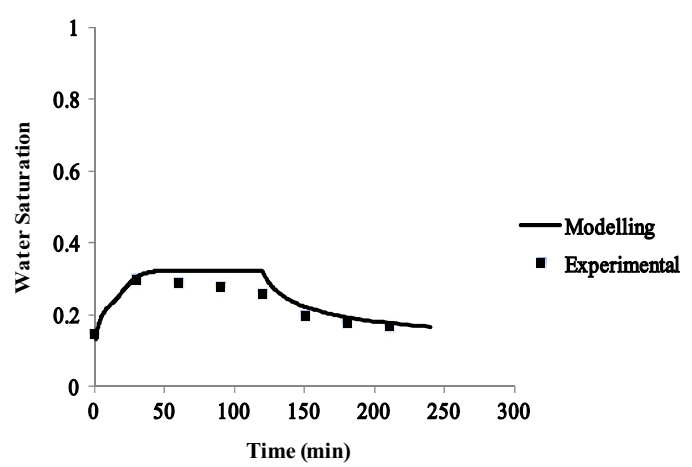

Figure 8. Variation in water saturation in the column during infiltration and drainage. (a) Sand column at $x=15 \mathrm{~cm}$; (b) Sand column at $x=5 \mathrm{~cm}$; (c) Soil column at $x=15 \mathrm{~cm}$; (d) Soil column at $x=5 \mathrm{~cm}$.

\subsection{Transport in unsaturated porous media}

The groundwater quality significantly depends on the transport in unsaturated zone, which the bio-colloid encounters first, in case the groundwater table is below the bottom of pit latrines, leaking septic tanks, leach pits etc. To assess the mobility of the bacteria under transient flow conditions, experiments were conducted as infiltration and drainage pulses.

3.5a Moisture movement: The changes in water saturation of sand and soil during the infiltration and drainage are shown in the figure $8 \mathrm{a}$ and $\mathrm{b}$. The temporal variation in moisture content was as per expectations. It was found to be increasing rapidly during the initial stages of infiltration, followed by almost a constant level due to constant infiltration rate. The moisture content started decreasing once the infiltration stopped and drainage began. Even after significant draining, the moisture content was slightly higher than that before the infiltration started. The travel time for wetting front to reach the bottom of the column was found to be 22 and 28 minutes, respectively, for sand and soil. The mathematical model results for water saturation obtained using the HYDRUS-1D software are shown in figure 8. It can be observed that the Hydrus-1D software, along with the van Genuchten parameters (obtained experimentally for soil and sand used here), is able to simulate the flow conditions during infiltration and drainage stages satisfactorily. This is a pre-condition for successful simulations for the transport of bacteria.

3.5b Transport of bacteria in the absence of substrate: The transport of active bacteria, in absence of substrate, through unsaturated sand and soil media is shown in the figure 9a. It can be observed that the transport was retarded in the unsaturated columns as compared to mobility in saturated conditions. For example, the $\mathrm{C} / \mathrm{C}_{\mathrm{o}}$ of live cells (in absence of substrate) in the effluent reduced from 0.68 under saturated conditions to 0.46 under unsaturated conditions, in sand column experiment. The temporal variation in bacterial concentrations was found to be influenced by changes in water content. The normalized concentration of cells in the effluent in the soil and sand media were found to be 0.39 and 0.46 , respectively. The colloid concentrations changed with changes in water content. The colloid concentration increased during the initial infiltration phase, remained at an almost constant value as long as the infiltration pulse continued and then reduced when drainage phase started. This trend agrees well with description of colloid mobilization during infiltration and rainfall events [50]. The increase in water content reduces mechanical and film straining of colloids in unsaturated sand by expanding flow pathways and enhancing pore water continuity. It was 
(a)

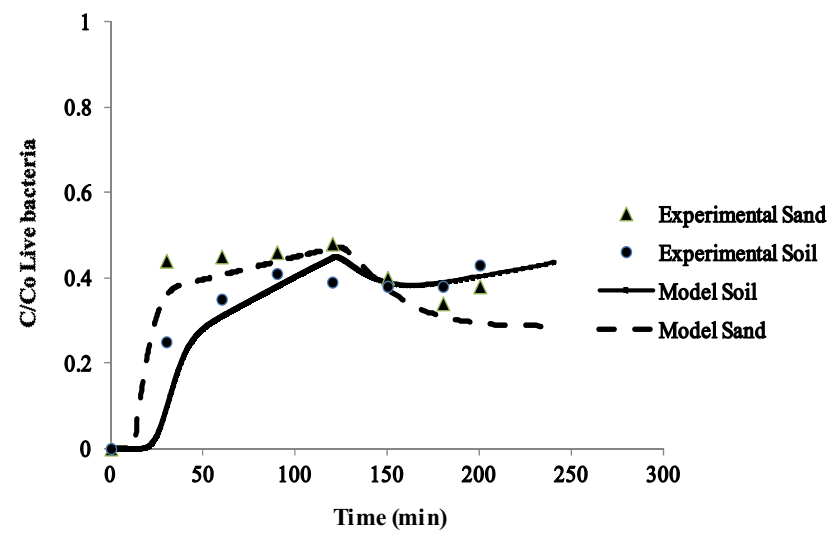

(b)

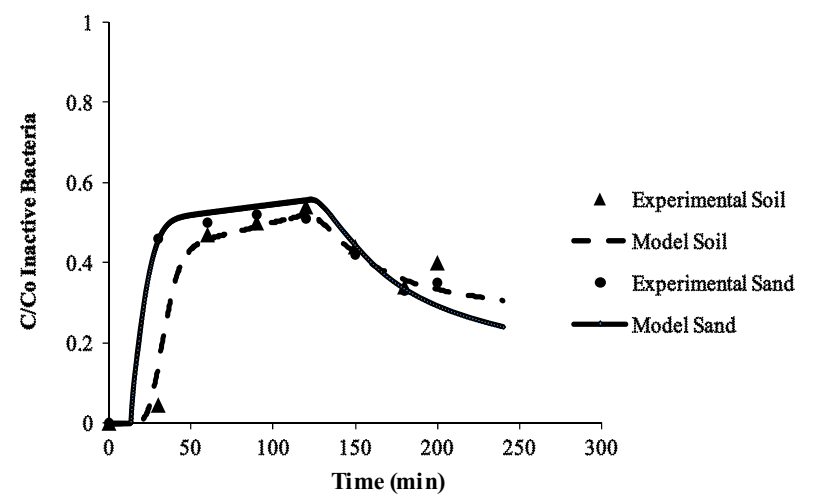

Figure 9. Transport of live and inactive cells in unsaturated sand and soil media. (a) Transport of live cells in unsaturated sand and soil media and (b) Transport of inactive cells in unsaturated sand and soil media.

also observed that colloids may get mobilized not only during infiltration phase but also during drainage phase. For the case of live cells (figure 9a), although the normalized concentration in the effluent decreased in the initial stages of drainage, it started increasing at later stages, in both soil and sand columns. The mobilization of colloids during infiltration and drainage was observed in the earlier studies also [51]. Similar trend was observed in case of inactive cells in soil column, but not in sand column (figure 9b). At this point of time, reasons for this behaviour are not clear. It may be due to the transient nature of moisture conditions at the wetting and drying fronts and how they affect the attachment and detachment processes in different soils. In addition, the presence of air phase could be having a distinct effect on the mobility [51]. Attraction of bacterial cells to the air-water interface could be high and the cells might have deposited at the air-water interface rather than at the porous media surface in the unsaturated experiments because the air-water interface is more hydrophobic than the porous media.

An attempt was made to model the bacterial transport under unsaturated conditions using the HYDRUS 1-D
Table 7. Transport parameters from the model in unsaturated column studies.

\begin{tabular}{lccccc}
\hline & \multicolumn{2}{c}{ Live } & & \multicolumn{2}{c}{ Inactive } \\
\cline { 2 - 3 } \cline { 5 - 6 } $\begin{array}{l}\text { Physiological } \\
\text { state/media type }\end{array}$ & $\begin{array}{c}k_{\mathrm{a}} \\
\left(\mathrm{min}^{-1}\right)\end{array}$ & $\begin{array}{c}k_{\mathrm{str}} \\
\left(\mathrm{min}^{-1}\right)\end{array}$ & & $\begin{array}{c}k_{\mathrm{a}} \\
\left(\mathrm{min}^{-1}\right)\end{array}$ & $\begin{array}{c}k_{\text {str }} \\
\left(\mathrm{min}^{-1}\right)\end{array}$ \\
\hline Sand & 0.015 & 0.015 & & 0.01 & 0.01 \\
Soil & 0.02 & 0.02 & & 0.012 & 0.012 \\
\hline
\end{tabular}

software, accounting for attachment and straining. The attachment and straining constants are given below in table 7 . These values are determined such that the simulated values best fit the observed breakthrough values. As shown in figure 9a, the model fitted values match with the observed breakthrough curves satisfactorily. The processes of deposition on the porous media and the air-water interfaces were lumped into a single attachment co-efficient and the film and pore straining into a single straining coefficient. The coefficients for attachment and straining (table 7) were found to be well within the range suggested values in the literature [25]. As expected, the percent mass retained increased with decreasing pore size (sand and soil) due to enhanced straining. The increase in normalized concentration of bacteria in the effluent during the lateral stages of drainage was well simulated by the Hydrus-1D model in case of soil, but not in case of sand.

Bacterial inactivation may occur during transport due to unfavourable conditions for bacterial survival [40]. Therefore, understanding the transport of inactive bacteria through unsaturated medium would help in evaluating the extent of bacterial contamination in groundwater. Transport experiment was carried out with the inactive bacterial suspension in soil and sand media, under infiltration conditions, followed by drainage conditions. These results are presented in figure $9 \mathrm{~b}$. The peak $\mathrm{C} / \mathrm{C}_{0}$ at the outlet was 0.45 and 0.50 in soil and sand media, respectively. These values are higher compared to those for live cells, which indicate that metabolically inactive cells penetrate farther than the active cells. This result is similar to the results obtained in the case of saturated conditions. Peak breakthrough concentrations for inactive cells, in absence of substrate, were found to be 0.74 and 0.61 , in the case of saturated experiments in sand and soil media. Significant effect of saturation level on transport of bacteria in porous media was observed by Jiang et al [20] and Chen and Walker [21]. Here again, the HYDRUS 1-D model could satisfactorily fit the breakthrough curves. The experiments revealed an increase in concentration at the end of the drainage phase in case of soil. HYDRUS 1-D model could not capture this effect. Also, as for the case of saturated conditions, the attachment and straining coefficients were higher for metabolically active bacteria than those for inactive bacteria in sand and soil media (table 7). The correlation coefficients for the matching between experimental data 
Table 8. Correlation coefficients for unsaturated column experiments.

\begin{tabular}{lcc}
\hline No & Experiment & $R^{2}$ \\
\hline 1 & Live, sand & 0.90 \\
2 & Inactive, sand & 0.98 \\
3 & Live, soil & 0.97 \\
4 & Inactive, soil & 0.96 \\
\hline
\end{tabular}

and the results obtained using HYDRUS 1-D model are more than 0.9, as given in table 8. This indicates that HYDRUS 1-D model, with the option of separate sites for kinetic attachment and straining, can be satisfactorily used to model the bacterial transport in unsaturated sand and soil media.

3.5c Transport of bacteria in the presence of substrate: Leakage from septic tanks and soak pits allows organic matter to enter the subsurface along with the bacteria. So, it is important to study the transport of bacteria along with substrate. The transport experiment was carried out for transport of bacterial suspension along with substrate. The experiment was conducted under infiltrating conditions, followed by drainage conditions. These results for unsaturated soil and sand media are presented in figure 10 . The peak normalized concentrations in the effluent at the outlet in soil and sand media were 0.72 and 0.76 , respectively. These values are higher than the peak effluent concentrations in the case of transport of live cells without substrate in unsaturated soil media (figure 9). The increase might be attributed to lesser generation time of $E$. coli in presence of substrate. Also, the organic matter is found to enhance the stability of colloidal suspension, leading to increased colloidal mobility [52]. Leaching experiments have shown that soils with higher organic matter content showed more colloid release, which is likely caused by increased amount of dissolved organic matter [53]. Also, in all the experimental runs in unsaturated condition, the breakthrough concentrations were higher in sand compared to soil media, owing to change in media characteristics. An attempt has been made to simulate the bacterial transport in the unsaturated columns, in presence of substrate, without considering the bacterial growth. It may be noted that the HYDRUS-1D model did not have the option for accounting for the bacterial growth in presence of substrate. However, measured variation of inlet bacterial concentration was specified as the inlet boundary condition. Although the model could simulate the experimental data in the initial stages, the mathematical model failed to simulate the fate and transport in the latter stages (figure 9). This may be due to (i) not considering the bacterial growth and (ii) change in bacterial attachment and detachment characteristics due to bacterial growth in presence of substrate.

It is to be noted here that the models presented for bacterial transport under both saturated and unsaturated (a)

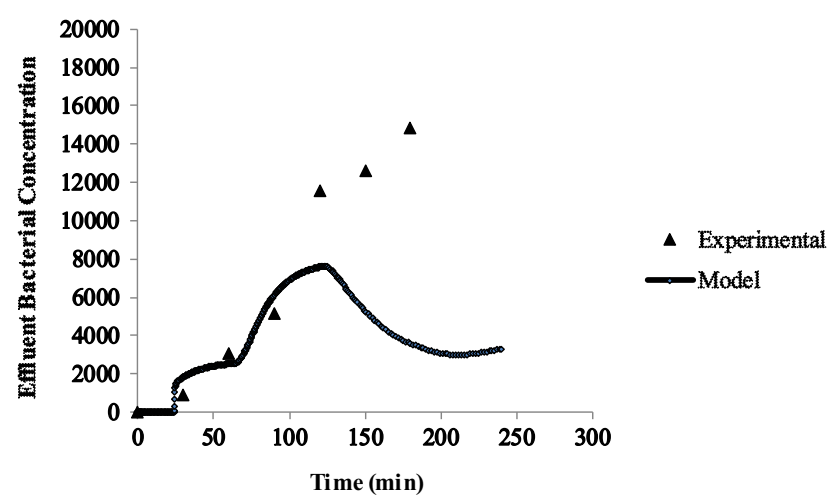

(b)

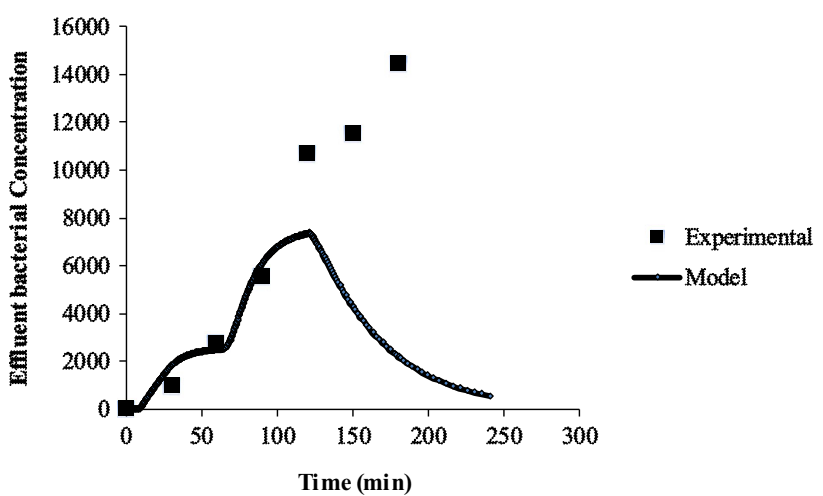

Figure 10. Transport of live cells with substrate in unsaturated soil and sand media. (a) Transport of live cells with substrate in unsaturated sand media and (b) Transport of live cells with substrate in unsaturated soil media.

conditions are based on several simplifying assumptions. Chief among them are the assumptions that (i) the sand and soil columns are homogeneous and (ii) the porosity and the structure of the soil column do not change with time. The dependence of soil hydraulic properties such as hydraulic conductivity and dispersivity on the scale of the experiment was also not considered. More importantly, even though the soil column was packed homogeneously to start with, this homogeneity might have been lost due to bacterial deposition during the course of experiment. Several earlier studies have indicated that contaminant load could alter the hydraulic and geotechnical characteristics of clayey and sandy soils [54, 55]. In the saturated flow experiments, bacterial deposition might have altered the porosity of the system, and therefore, the pore velocity and depositional rate constants. In the unsaturated flow experiments, the bacterial deposition could alter the van Genuchten parameters also. These changes to characteristics of soil column depend on time, distance from inlet and the amount of bacteria present. Especially, in presence of substrate, these effects get accentuated due to bacterial growth. In the mathematical model used here, these complex time-dependent effects were not simulated. 


\section{Conclusion}

The present study was conducted to understand the complex interaction between the effects of (i) physiological state (active vs. inactive) of bacteria, (ii) presence/absence of substrate, (iii) soil type (sand and soil), (iv) flow conditions (intermittent vs. continuous; saturated vs. unsaturated) and (v) flow velocity, on the transport of bacteria through a porous medium. It has been found that inactive cells move farther than the active cells, and this effect is of the same order of magnitude for transport through both sand and soil media. While there was a $29.5 \%$ increase in normalized breakthrough concentration in the sand column as the velocity increased four-fold, the increase in breakthrough concentration was only $20 \%$ in the case of soil. In case of both sand and soil, normalized breakthrough concentrations were significantly higher when substrate was present as compared to when it was absent. Results from the present study indicate that the loading conditions and the growth of bacteria due to availability of substrate could alter the retention of bacteria significantly. Unlike the earlier observations for the case of pulse input, normalized breakthrough concentrations increased as the inlet concentration increased in the case of continuous input. For the same bacteria and type of porous medium, unsaturated conditions resulted in more bacterial retention as compared to that in case of saturated conditions. It was also found that existing mathematical models based on macroscopic advection-dispersion-filtration equations could satisfactorily simulate the bacterial transport, when substrate was absent. Mathematical model could not simulate the bacterial transport under growth conditions when the substrate was present. Results of this work have shed more light on the groundwater contamination due to leaking septic tanks and leach pits.

\section{References}

[1] Łuczkiewicz A and Quant B 2007 Soil and groundwater fecal contamination as a result of sewage sludge land application. J. Environ. Stud. 16: 587-593

[2] USAID 2010 A rapid assessment of septage management in Asia USAID. Bangkok: Regional Development Mission for Asia, p. 127

[3] Valencia R den Hamer D, Komboi J, Lubberding H J and Gijzen H J 2009 Alternative treatment for septic tank sludge: co-digestion with municipal solid waste in bioreactor landfill simulation. J. Environ. Manag. 90(2): 940-945

[4] Laluraj C M and Gopinath G 2015 Assessment on seasonal variation of groundwater quality of phreatic aquifers. A river basin system. Environ. Monitor. Assess. 117(1-3): 145-157

[5] Sunderrajan K 2011 On-site sanitation and groundwater contamination: a policy and technical review. India: INREM, pp. 2-4

[6] Foppen J W A and Schijven J F 2006 Evaluation of data from the literature on the transport and survival of Escherichia coli and thermotolerant coliforms in aquifers under saturated conditions. Water Res. 40: 401-426

[7] Keller A A and Auset M 2007 A review of visualization techniques of biocolloid transport processes at the pore scale under saturated and unsaturated conditions. Adv. Water Resour. 30: 1392-1407

[8] Jansen S, Vereecken H and Klumpp E 2010 On the role of metabolic activity on the transport and deposition of Pseuomonas fluorescens in saturated porous media. Water Res. 44(4): 1288-1296

[9] Sanin F D and Bryers J D 2003 Effect of starvation on the adhesive properties of xenobiotic degrading bacteria. Process Biochem. 38: 909-914

[10] Li J, Zhao X, Tian X, Li J, Sjollema J and Wang A 2015 Retention in treated wastewater affects survival and deposition of Staphylococcus aureus and Escherichia coli in Sand Columns. Appl. Environ. Microbiol. 81(6): 2199-2205

[11] Xu S, Liao Q and Saiers J E 2007 Straining of non-spherical colloids in saturated porous media. Environ. Sci. Technol. 42(3): 771-778

[12] Lutterodt G, Foppen J W A and Uhlenbrook S 2014 Escherichia coli strains harvested from springs in Kampala, Uganda: cell characterization and transport in saturated porous media. Hydrol. Process 28: 1973-1988

[13] Sen T K 2010 Processes in pathogenic biocolloidal contaminants transport in saturated and unsaturated porous media: a review. Water Air Soil Pollut. 216(1-4): 239-256

[14] Bitton G, Lahav N and Henis Y 1974 Movement and retention of Klebsiella aerogenes in soil columns. Plant Soil 40: 373-380

[15] Tan Y, Bond W J and Griffin D M 1992 Transport of bacteria during unsteady unsaturated soil water flow. Soil Sci. Soc. Am. J. 56: 1331-1340

[16] Huysman F and Verstraete W 1993 Water-facilitated transport of bacteria in unsaturated soil columns: influence of cell surface hydrophobicity and soil properties. Soil Biol. Biochem. 25: 83-90

[17] Jewett D G, Logan B E, Arnold R G and Bales R C 1999 Transport of Pseudomonas fluorescens strain P17 through quartz sand columns as a function of water content. $J$. Contam. Hydrol. 36: 73-89

[18] Gargiulo G, Bradford S A, Šimůnek J, Ustohal P, Vereecken $\mathrm{H}$ and Klumpp E 2007 Bacteria transport and deposition under unsaturated conditions: the role of bacteria surface hydrophobicity. Vadose Zone J. 7(2): 406-419

[19] Powelson D K and Mills A L 1998 Water saturation and surfactant effects on bacterial transport in sand columns. Soil Sci. 163: 694-704

[20] Jiang S, Pang L, Buchan G D, Simůnek J, Noonan M J and Close M E 2010 Modeling water flow and bacterial transport in undisturbed lysimeters under irrigations of dairy shed effluent and water using HYDRUS-1D. Water Res. 44(4): 1050-1061

[21] Chen G and Walker S L 2012 Fecal indicator bacteria transport and deposition in saturated and unsaturated porous media. Environ. Sci. Technol. 46(16): 8782-8790

[22] Rao S M, Sekhar M and Raghuveer Rao P 2013 Impact of pit-toilet leachate on groundwater chemistry and role of vadose zone in removal of nitrate and $E$. coli pollutants in Kolar District, Karnataka, India. Environ. Earth Sci. 68(4): 927-938 
[23] DeNovio N M, Saiers J M and Ryan J N 2004 Colloid movement in unsaturated porous media: recent advances and future direction. Vadose Zone J. 3: 338-351

[24] Auset M, Keller A A, Brissaud F and Lazarova V 2005 Intermittent filtration of bacteria and colloids at pore and column scales. Water Resour. Res. 41. doi:10.1029/ 2004WR003611

[25] Bradford S A and Torkzaban S 2008 Colloid transport and retention in unsaturated porous media: a review of interface, collector, and pore-scale processed and models. Vadose Zone J. 7: 667-681

[26] Bradford S A, Wang Y, Kim H, Torkzaban S and Šimůnek J 2014 Modeling microorganism transport and survival in the subsurface. J. Environ. Q. 43: 421-440

[27] Lenhart J J and Saiers J E 2002 Transport of silica colloids through unsaturated porous media: experimental results and model comparisons. Environ. Sci. Technol. 36: 769-777

[28] IS 2720. IS 2720-22: Methods of test for soils. New Delhi, India: Bureau of Indian Standards

[29] IS 2720.1980 IS 2720-3-1: Methods of test for soils. New Delhi, India: Bureau of Indian Standards

[30] Rosenberg M, Gutnick D and Rosenberg E 1980 Adherence of bacteria to hydrocarbons: a simple method for measuring cell-surface hydrophobicity. FEMS Microbiol. 9: 29-33

[31] Dubois M, Gill K A, Hamilton J K, Rebers P A and Smith F 1958 Colorimetric method for determination of sugar and related substances. J. Anal. Chem. 28: 350-356

[32] Datta A and Philip L 2012 Biodegradation of volatile organic compounds from paint industries. Appl. Biochem. Biotechnol. 167(3): 564-580

[33] Somasundaram V, Philip L and Bhallamudi S M 2011 Laboratory scale column studies on transport and biotransformation of $\mathrm{Cr}$ (VI) through porous media in presence of CRB, SRB and IRB. Chem. Eng. J. 171(2): 572-581

[34] Lowry O H, Rosenbrough N J, Farr A L and Randall R J 1951 Protein measurement with the folin phenol reagent. $J$. Biol. Chem. 193: 265-275

[35] Bradford S A, Simunek J, Bettahar M, van Genuchten M Th and Yates S R 2003 Modeling colloid attachment, straining, and exclusion in saturated porous media. Environ. Sci. Technol. 37: 2242-2250

[36] Mishra C, Manikandan S T, Bhallamudi S M and Panday S 2012 Dynamic subtiming-based implicit nonoscillating scheme for contaminant transport modelling. J. Hydrol. Eng. 17: 694-703

[37] Šimunek J, van Genuchten M Th and Šejna M 2005 The HYDRUS-1D software package for simulating the one-dimensional movement of water, heat, and multiple solutes in variably saturated media. Version 3.0, HYDRUS Software Series 1, Department of Environmental Sciences, University of California Riverside, Riverside, CA Department of Environmental Sciences, University of California Riverside, Riverside, CA 270

[38] Gargiulo G, Bradford S A, Simunek J, Ustohal P, Vereeckan H and Klumpp E 2007 Transport and deposition of metabolically active and stationary phase Deinococcus radiodurans in unsaturated porous media. Environ. Sci. Technol. 41: 1265-1271

[39] Guber A K, Shelton D R and Pachepsky Y A 2005 Effect of manure on Escherichia coli attachment to soil. J. Environ. Q. 34: 2086-2089
[40] Nola M, Njiné T, Boutin C, Servais P, Messouli M, Bidjeck L M N, Monkiedje A, Zébazé Togouet S H and Kemka N 2005 Sorption kinetics of Escherichia coli and Salmonella sp on two soil layers associated with a groundwater table in Yaounde, Cameroon (Central Africa). Int. J. Environ. Res. Public Health 2: 447-455

[41] Guzman J A, Fox G A and Penn C A 2012 Sorption of Escherichia coli in agricultural soils influenced by swine manure constituents. Am. Soc. Agric. Biol. Eng. 55: 161-71

[42] Zhong H, Jiang Y, Zeng G, Liu Z, Liu L, Liu Y, Yang X, Laia M and He Y 2015 Effect of low-concentration rhamnolipid on adsorption of Pseudomonas aeruginosa ATCC 9027 on hydrophilic and hydrophobic surfaces. J. Hazard. Mater. 285: 383-388

[43] Poccia M E, Beccaria A J and Dondo R G 2014 Modeling the microbial growth of two Escherichia coli strains in a multisubstrate environment. Braz. J. Chem. Eng. 31(2): 347-354

[44] Schumacher J G 2002 Transport, and sources offecal bacteria in streams and survival in land-applied poultry litter in the Upper Shoal Creek Basin, Southwestern Missouri U.S. Geological Survey Water-Resources Investigations Report, vol. 3

[45] Senn H, Lendenmann U, Snozzi M, Hamer G and Egli T 1994 The growth of Escherichia coli in glucose-limited chemostat cultures: a re-examination of the kinetics. Biochem. Biophys. Acta 1210(3): 424-436

[46] Walczak J J, Wang L, Bardy S L, Feriancikova L, Li J and Xu S 2012 The effects of starvation on the transport of Escherichia coli in saturated porous media are dependent on $\mathrm{pH}$ and ionic strength. Colloids Surf. B Biointerfaces 90: 129-136

[47] Weiss T H, Mills A L, Hornberger G M and Herman J S 1995 Effect of bacterial cell shape on transport of bacteria in porous media. Appl. Environ. Microbiol. 29: 1737-1740

[48] Chilton J and Seiler K P 2006 Groundwater occurrence and hydrogeological environments. In: Schmoll O (ed.) Protecting groundwater for health: managing the quality of drinking-water sources. London International Water Association, pp. $21-47$

[49] Stevik T K, Kari A, Ausland G and Hanssen J F 2004 Retention and removal of pathogenic bacteria in wastewater percolating through porous media: a review. Water Res. 38: 1355-1367

[50] Zhuang J, Tyner J S and Perfect E 2009 Colloid transport and remobilization in unsaturated porous media during transient flow. J. Hydrol. 377: 112-119

[51] Cheng T and Saiers J E 2009 Mobilization and transport of in situ colloids during drainage and imbibition of partially saturated sediments. Water Resour. Res. 45. doi:10.1029/ 2008WR007494

[52] McGraw M A and Kaplan D I 1997 Colloid suspension stability and transport through unsaturated porous media Report. PNNL-11565, Pacific Northwest National Laboratory, Richland, Washington

[53] Laegdsmand M, Jonge L W de and Moldrup P 2005 Leaching of colloids and dissolved organic matter from columns packed with natural soil aggregates. Soil Sci. 170: 13-27

[54] Fallah M, Shabanpor M and Ebrahimi S 2015 Evaluation of petroleum impacts on some properties of loamy sand soil with the main focus on hydraulic properties. Environ. Earth Sci. 74: 4751-4762

[55] Khamehchiyan M, Charkhabi A H and Tajik M 2007 Effects of crude oil contamination on geotechnical properties of clayey and sandy soils. Eng. Geol. 89: 220-229 